\title{
Estimation of the low-density (beta) lipoproteins of serum in health and disease using large molecular weight dextran sulphate
}

\author{
K. W. WALTON AND P. J. SCOTT ${ }^{1}$ \\ From the Department of Experimental Pathology, University of Birmingham
}

SYNOPSIS Studies have been made of the factors affecting the specificity of the interaction between high molecular weight dextran sulphate and low-density lipoproteins, both in pure solution and in serum. The results have been used in the development of a simple assay method for the serum concentration of low-density lipoproteins in small volumes of serum. The results obtained by this assay procedure have been found to correlate acceptably with parallel estimations of low-density lipoproteins by an ultracentrifugal technique and by paper electrophoresis.

The technique has been applied to a survey of serum levels of these proteins in a normal population. The results have been compared with data in the literature. Satisfactory agreement was found between mean levels, matched for age and sex, between the dextran sulphate method and those methods based ultimately on chemical estimation of one or more components of the isolated lipoproteins. A systematic difference was observed when the dextran sulphate method was compared with estimates based on analytical ultracentrifugation or turbidimetry using amylopectin sulphate.

Some indication of the range of application of the dextran sulphate method in clinical chemistry is provided.

When density is used as the defining parameter, the protein-bound lipids of human serum are divisible into three categories: the chylomicra (density less than $0.95 \mathrm{~g} . / \mathrm{ml}$.); low-density (0.96-1.062 g. $/ \mathrm{ml}$.) lipoproteins; and high-density (greater than 1.065 g./ml.) lipoproteins.

Of these, the low-density lipoproteins show the most marked changes with age, sex, and between population groups. Within any one population group, these proteins also show marked variation in concentration in certain disease states. In recent years, interest has centred particularly on the association of increase in serum low-density lipoprotein levels with the occurrence of atherosclerosis (cf. Gofman, Glazier, Tamplin, Strisower, and DeLalla, 1954).

Detailed information concerning concentration, molecular distribution, and composition of these lipoproteins is obtainable by ultracentrifugation, supplemented by electrophoretic and immunological techniques. But these procedures are timeconsuming and demand specialized equipment and

\footnotetext{
${ }^{1}$ Present address: Medical Unit, Auckland Hospital, Auckland, New Zealand.

Received for publication 18 March 1964.
}

highly trained and skilled personnel. There is still a need for a simple, rapid and specific method, within the capacity of any reasonably equipped laboratory, which will provide at least an estimate of the overall concentration of these lipoproteins.

The following method (developed in this laboratory primarily as a screening procedure allowing the selection of sera for detailed characterization by more elaborate physico-chemical methods) appears to fulfil this need and is proffered as one which may find application both in routine clinical use and possibly also in population survey work.

Its use for the latter purpose is illustrated by accounts of investigation of the ranges of variation of serum levels of these proteins encountered $(a)$ in healthy males and females of various ages; $(b)$ during repeated observations on a given healthy individual; and $(c)$ in cases of thyroid dysfunction.

\section{MATERIALS AND METHODS}

DEXTRAN SULPHATE The materials used in the development of this method were prepared by Dr. C. R. Ricketts from dextran of intrinsic viscosity 0.485 . The dextran was sulphated as described by Ricketts (1952) to 
yield batches varying in sulphur content between 12.2 and $18.2 \%$ by weight and corresponding to molecular weights of 446,000 to 648,000 . Dextran sulphate was used in solutions containing $0.5 \mathrm{~g} . / 100 \mathrm{ml}$. (w/v) in $0 \cdot 1 \mathrm{M}$ calcium acetate or calcium chloride, except where otherwise stated.

Dextran sulphate of molecular weight approximately 500,000 is available commercially from Pharmacia Ltd., Uppsala, Sweden, and has been found to be equally suitable.

For the assay method a solution of $0.5 \mathrm{~g} . / 100 \mathrm{ml}$. was prepared in $0 \cdot 1 \mathrm{M}$ calcium acetate or calcium chloride.

CALCIUM SOlutions Calcium acetate $0 \cdot 1 \mathrm{M}$ was used in the initial studies. Later $0 \cdot 1 \mathrm{M}$ calcium chloride was substituted and incorporated in the buffer used (see below).

BUFFER SOLUTION For the initial experiments, sodium diethylbarbitone/hydrochloric acid buffer at $p \mathrm{H} 9.0$ was used. Later, the following calcium-containing buffer was devised:

Sodium diethylbarbitone $\ldots \ldots \ldots 18.040 \mathrm{~g}$.

Calcium chloride ..............1.429 g.

N. hydrochloric acid .........5.90 ml.

Distilled water to ............. litre

The $p H$ should be $9 \cdot 0 \pm 0.05$.

LOW-DENSITY LIPOPROTEIN STANDARD SOLUTIONS These were prepared from lipoprotein freeze dried in sucrose and isolated by the method of Oncley, Walton, and Cornwell (1957) from pooled normal human plasma. The concentration of lipoprotein in the standard freeze-dried material was measured by the dried weight procedure of Russ, Raymunt, and Barr (1956). Material prepared from two separate large plasma pools was compared and no difference was demonstrable between them. In each case the preparation was found to be $98 \%$ pure as judged by electrophoretic and immunological techniques. For the latter, the quantitative gel-diffusion precipitin method of Soothill (1962) was used. This method was also used to judge the specificity and completeness of precipitation of low-density lipoproteins by dextran sulphate. Standard solutions of lipoprotein of varying strengths were made up in $0 \cdot 15 \mathrm{M}$ sodium chloride and used immediately.

STORAGE OF REAGENTS Stock solutions of all reagents were stored frozen, $0.01 \%$ sodium azide being added to prevent bacterial and fungal growth while solutions were in the thawed state.

ULTRACENTRIFUGAL PROCEDURES The ultracentrifugal analysis of serum was carried out by a saline density gradient method essentially similar to that of Havel, Eder, and Bragdon (1955). Sub-fractions were further characterized, where necessary, in the model E Spinco analytical ultracentrifuge in a saline solution of density $1.063 \mathrm{~g} . / \mathrm{ml}$. as described by DeLalla and Gofman (1954).

MEASUREMENT OF OPTICAL DENSITY This was carried out at $680 \mathrm{~m} \mu$ in standard glass cells in a spectrophotometer. At various times, the Unicam SP.500 and SP.600 instru- ments and the Hilger Uvispek were employed. It was found these instruments could be used interchangeably without affecting the results.

RADIO-IODINATION Samples of purified low-density lipo- $\frac{\overline{\frac{O}{5}}}{\overline{\frac{D}{2}}}$ protein and of human albumin were subjected to radioiodination by a modification of a technique described by $\Omega$ McFarlane (1956).

RADIOACTIVITY MEASUREMENTS Gamma-ray counting of $\vec{\circ}$ ${ }^{131}$ I-labelled low-density lipoproteins was performed in a $\vec{\longrightarrow}$ standard well-type thallium-activated sodium iodide $\omega$ crystal scintillation counter. Counting times were designed to ensure a total of 2,500 counts above background, i.e., a counting accuracy of $\pm 4 \%$.

PLASMA FRACTIONATION This was carried out by the cold-ethanol fractionation procedure of Cohn et al., as $\mathrm{V}$ described by Strong (1948).

Estimation of low-density lipoproteins by the immunocrit' procedure of Heiskell, Fisk, Florsheim, Tachi, $z$ Goodman, and Carpenter (1961) was carried out with $O$ the Beta-L test kit supplied by Baxter Laboratories Ltd., \} High Wycombe, Bucks.

'NORMAL' SERA Venous blood samples were obtained from students, laboratory technicians, and staff of the Medical School and Queen Elizabeth Hospital, Birming- + ham. Sera were also obtained from out-patients attending the latter hospital for minor complaints or for late convalescent follow-up appointments. These sera were supplemented with samples from selected in-patients who had been fully ambulant, in apparent good health, and 응 who had been admitted for such 'cold' surgical procedures $\varrho$ as hernia repair or tonsillectomy. Analysis of the grouped $\overrightarrow{\vec{O}}$ frequency distributions by age of serum low-density 3 lipoprotein levels between in-patient 'normals' and the $\bar{Z}$ other groups showed no significant difference of distri- $\overline{0}$ bution.

Only 12 sera from children under 14 years of age were obtained from the foregoing sources. These were supple- 0 mented with blood samples similarly selected from 3 in-patients and out-patients attending the Children's Hospital, Birmingham.

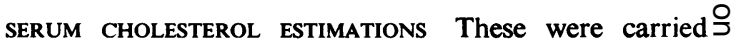
out by the methods of Henly (1957) and of Crockson $D$ (1962).

\section{EXPERIMENTAL}

INVESTIGATION OF THE INTERACTION OF DEXTRANN SUlPHATE WITH PlASMA PROTEINS Preliminaryo experiments with solutions of freeze-dried Cohn fractions of normal human plasma showed that at $\frac{}{\Phi}$ physiological $p \mathrm{H}$ the addition of dextran sulphate $\stackrel{\infty}{+}$ produced marked precipitation in Cohn fractions $I_{T}$ and III, slight precipitation in Cohn fraction II, $\bar{O}$ and no effect in Cohn fractions IV, V, and VI.

The major component precipitated from fraction $\frac{\rho}{\vec{B}}$ $I$, in confirmation of the earlier finding by Walton 
(1952), was found to be fibrinogen. It was found that there was partial precipitation of 7S- and 19S- $\gamma$ globulin from fraction II while the component precipitated from fraction III was almost exclusively low-density lipoprotein.

At $p \mathrm{H} \mathrm{9.0,} \mathrm{on} \mathrm{the} \mathrm{other} \mathrm{hand,} \mathrm{minimal} \mathrm{precipi-}$ tation of fibrinogen occurred with dextran sulphate, as previously noted (Walton, 1952; Sasaki and Noguchi, 1959) and only traces of $\gamma$-globulins were precipitated but strong interaction still occurred with the low-density lipoprotein. However, the complex was unstable in the absence of added calcium ions, tending to re-dissolve on standing.

On the other hand, the addition of $0 \cdot 1 \mathrm{M}$ calcium acetate or calcium chloride to the system produced irreversible and stable precipitation of the lowdensity lipoprotein. Centrifugation of the precipitate followed by immunological testing of the supernatant showed that removal of low-density lipoprotein, in these circumstances, was virtually complete.

In view of these observations, the factors influencing optimal interaction of dextran sulphate with the low-density lipoproteins were investigated systematically and quantitatively.

Effect of calcium ion concentration The effect, at $p \mathrm{H} \mathrm{9.0,} \mathrm{on} \mathrm{the} \mathrm{interaction} \mathrm{between} \mathrm{purified} \mathrm{low-}$ density lipoproteins at various concentrations and dextran sulphate, of variation of the calcium content of the system is illustrated in Figure 1. It will be observed that in each case the precipitation curve reached a plateau. But this plateau was attained with a lower calcium ion concentration for lower lipoprotein concentrations.

When this experiment was repeated with ${ }^{131}$ Ilabelled sub-fractions of these lipoproteins, it was noted that a higher $\mathrm{Ca}$ ion concentration was needed to ensure maximal precipitation of the $S_{\mathrm{f}} 20-400$ sub-fraction than was necessary for the $S_{\mathfrak{f}} 3-9$ subfraction.

When a similar experiment was carried out with serum (Fig. 2) it was found that the precipitation curve was initially similar in shape but, after attaining a plateau, a second further increase in precipitation occurred. Examination of the composition of the precipitate at various points on this curve showed that from its origin to the termination of the plateau portion the precipitate contained lowdensity lipoprotein alone. On the other hand, the secondary rise in the curve appeared to be due to the precipitation of 7S- and 19S- $\gamma$ globulin in addition.

When serum was artificially enriched with lowdensity lipoprotein, the general shape of the precipitation curve was unchanged though it was displaced upward (Fig. 2).

These observations suggested that the amount of

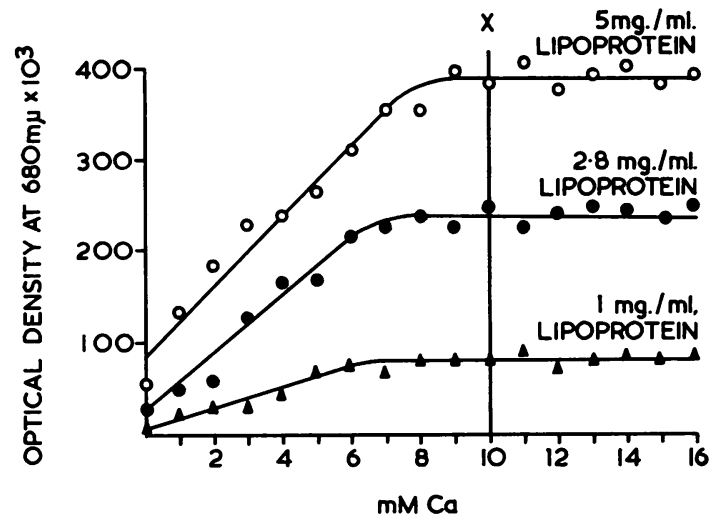

FIG. 1. The effect of variation of calcium ion concentration on the interaction between dextran sulphate and isolated low-density lipoproteins. $\bigcirc=5 \mathrm{mg} . / \mathrm{ml}$., $\bigcirc=$ $2.8 \mathrm{mg} . / \mathrm{ml} ., \triangle=1.0 \mathrm{mg} . / \mathrm{ml}$. lipoprotein. The point $X$ corresponds to the concentration of calcium ions adopted for the standard assay procedure (see text).

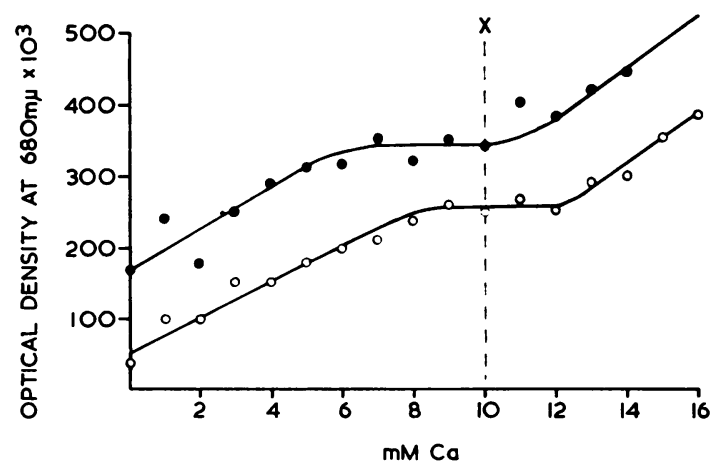

FIG. 2. The effect of variation of calcium ion concentration on the interaction between dextran sulphate and low-density lipoproteins in serum. $X$ as in Figure $1.0=$ unenriched normal serum. $=$ the same serum enriched with isolated low-density lipoproteins. Note secondary rise in optical density (due to co-precipitation of $\gamma$-globulin) at high Ca ion concentration (compare with Figure 1).

calcium present in the system was critical in that a certain 'threshold' value must be present to attain maximal precipitation of low-density lipoprotein but that, if this amount was much exceeded, the interaction lost its specificity for the lipoproteins alone. Accordingly, a point (marked $X$ in Figs 1 and 2) within these limits was chosen and the calcium concentration corresponding to this point adopted for the assay method to be described.

Effect of dextran sulphate concentration When the $p \mathrm{H}$ was kept constant at $\mathbf{9 \cdot 0}$ and the calcium ion concentration fixed at the level previously judged optimal, it was found that varying amounts of 


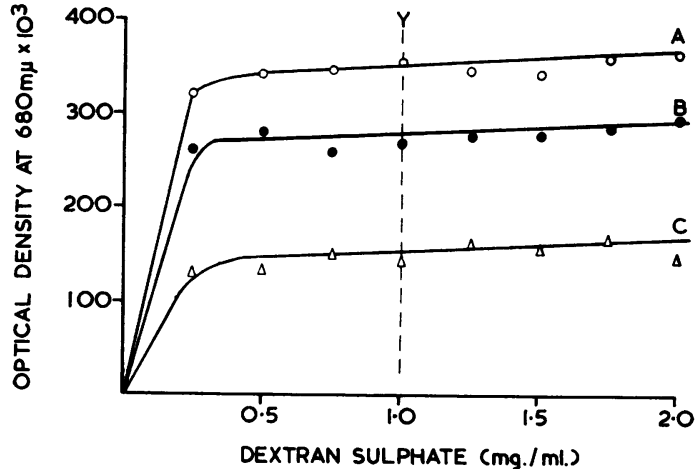

FIG. 3. The effect of variation of dextran sulphate concentration on precipitation of low-density lipoproteins at $\mathrm{pH} 9.0$ and in the presence of $10 \mathrm{mM} \mathrm{Ca}$. The point $\mathrm{Y}$ corresponds to the concentration of dextran sulphate adopted for the standard assay procedure. $\bigcirc=$ normal serum $A ; O=$ normal serum $B ; \triangle=$ isolated low-density lipoprotein in $0.15 \mathrm{M}$ sodium chloride.

dextran sulphate added to low-density lipoprotein solutions over a range from 250 to $1,000 \mathrm{mg}$./100 ml., or to whole serum, once again gave a series of precipitation curves of similar shape, each levelling off to a flat plateau (Fig. 3). Examination of the supernatants from precipitates in the plateau region by an immunological method confirmed that (within the limits of error of this technique, Soothill, 1962) the low-density lipoprotein had been removed completely. Although it has been shown that sulphated polysaccharide-protein complexes redissolve in the presence of great excess of the sulphated polysaccharide (Walton, 1952; Bernfeld, Nisselbaum, Berkeley, and Hanson, 1960) it was found that the amount of dextran sulphate necessary to produce this effect was greatly in excess of the range shown.

Accordingly, a point well along the plateau (marked $Y$ in Fig. 3) was chosen and the concentration of dextran sulphate corresponding to this adopted for the assay method to be described. In this way, a moderate excess of dextran sulphate was provided to allow for possible weighing errors in the preparation of standard solutions or pipetting errors.

Effect of variation in sulphur content and molecular size of dextran sulphate Three laboratory scale preparations containing respectively $12 \cdot 2,16 \cdot 0$, and $18.2 \%$ sulphur and two commercial preparations containing $17 \pm 0.5 \%$ sulphur were examined. It was found that all these preparations could be used interchangeably. The three laboratory scale preparations and one of the commercial batches were all of molecular weights around 500,000. The other commercial batch was of molecular weight approxi- mately $2 \times 10^{6}$. Preparations of this range of molecular size thus appeared to be equally effective? in precipitating low-density lipoproteins. But dextran? sulphate of similar sulphur content but much smaller molecular weight, corresponding to the material introduced for use as a clinical anticoagulanto (Ricketts, Walton, Van Leuven, Birbeck, Brown, „ొ Kennedy, and Burt, 1953), was found to be ineffectiveas was the parent dextran used for the preparationslisted above and a preparation of corresponding $\vec{\omega}$ molecular weight containing only $2 \%$ sulphur.

Effect of time and temperature Employing? reagents in the amounts finally adopted for serum $\vec{v}$ assay of low-density lipoproteins (see below), $\dot{\circ}$ reagent mixtures were warmed or cooled to various temperatures within the range $4^{\circ}$ to $25^{\circ}$ before and after the addition of standard amounts of low- -5 density lipoprotein. It was assumed that immediate transfer of these mixtures to spectrophotometer cellso and readings made rapidly did not affect the temperature of the mixtures sufficiently to invalidate 3 comparative readings. It was found that over this temperature range no significant differences in $\overrightarrow{0}$ optical density could be demonstrated in measure-o ments made following the addition of low-density lipoprotein solutions varying in concentration between 100 and $950 \mathrm{mg} . / 100 \mathrm{ml}$.

On the addition of dextran sulphate to solutionso containing low-density lipoproteins it was found\% that turbidity increased rapidly to a maximum ato five to 10 minutes. Thereafter, if tubes were allowed $\vec{F}$ to stand undisturbed the precipitate tended to 3 aggregate as floccules and readings were inconsistent. But if the tubes were shaken vigorously the precipitate became restored to a fine suspension and measurements made on tubes so treated, even after: storage for periods up to 24 hours at $4^{\circ} \mathrm{C}$., showed 3 no significant difference from the initial 10-minute reading.

Results were most reproducible if reagents were added in the order given below.

TECHNIQUE ADOPTED FOR STANDARD METHOD As a result of the preceding investigations the following procedures was adopted as a standard technique:

The following reagents were added, in the order specified, to a series of 3 in. $\times \frac{1}{2}$ in. test tubes.

1 Blank $4.8 \mathrm{ml}$. calcium barbitone buffer $0.2 \mathrm{ml}$. dextran sulphate solution

2 Unknown $4.6 \mathrm{ml}$. calcium barbitone buffer $0.2 \mathrm{ml}$. dextran sulphate solution $0.2 \mathrm{ml}$ serum or low-density lipoprotein solution

3 Control (to correct for inherent turbidity of serum) $4.8 \mathrm{ml}$. calcium barbitone buffer $0.2 \mathrm{ml}$. serum.

This tube sometimes showed a fine opalescenca웆

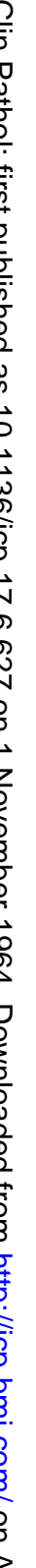


depending on the concentration of chylomicra in the initial serum specimen.

The tubes were allowed to stand at room temperature for five to 10 minutes. They were then inverted sharply twice to distribute the precipitate evenly and the optical densities of tubes (2) and (3) were read at $680 \mathrm{~m} \mu$ in the spectrophotometer using solution (1) as blank. If values exceeding an optical density of 1.0 were obtained, the procedure was repeated using $0.1 \mathrm{ml}$. serum and $4.5 \mathrm{ml}$. calcium barbitone buffer (the necessary allowance for this dilution being made by doubling the result obtained). Correction for inherent serum turbidity, where necessary, was made by subtracting the optical density reading of tube (3) from the corresponding tube (2) for the same specimen.

Derivation of results The optical density readings for tube series (2), corrected where necessary for inherent serum turbidity as detailed above, were multiplied by 1,000 and the corresponding concentration of low-density lipoprotein obtained from the calibration curve (Fig. 4).

Additional points It was found necessary to ensure that: 1 The initial serum or lipoprotein samples were free from shreds of fibrin, cellular debris etc. Traces of haemolysis were found not to interfere with the estimate. Plasma could not be used because of the interaction of dextran sulphate with fibrinogen. 2 Spectrophotometer cells were kept scrupulously clean and free from traces of detergents. 3 Since the volume of serum necessary was small, readings were carried out in duplicate to reduce the error of the method and increase reproducibility. It was found that the critical measurement was that of the $0.2 \mathrm{ml}$. volume of serum. The method tolerated slight inaccuracies in the pipetting of the other reagents.

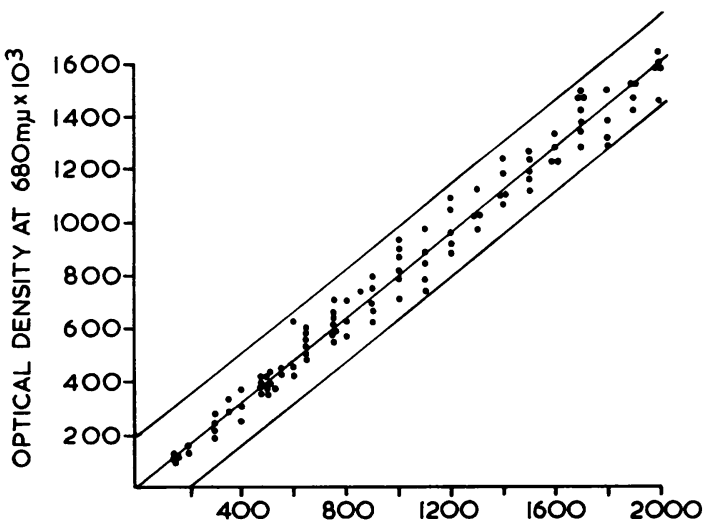

LOW DENSITY LIPOPROTEIN (mg./100mI.)

FIG. 4. Calibration curve for standard assay procedure, showing the turbidity produced on the addition of dextran sulphate, under the conditions adopted for the standard assay procedure, to known concentrations of isolated low-density lipoprotein (concentrations derived from driedweight determination). The calculated regression $(r=$ $0.970 ;$ slope $=38^{\circ} 37^{\prime}$ ) is shown with $95 \%$ confidence limits.

\section{RESULTS}

CALIBRATION OF METHOD AGAINST A LIPOPROTEIN STANDARD The calibration curve shown in Fig. 4 was compiled from results obtained by the application of the procedure outlined to a series of standard solutions of purified low-density lipoprotein of known concentration (obtained by dried weight determinations). The correlation coefficient $(r)$ for the slope obtained was 0.970 with a standard deviation of 76 (units of optical density $\times 1,000$ ) over the range 200 to $800 \mathrm{mg}$. $/ 100 \mathrm{ml}$. low-density lipoprotein.

VERIFICATION OF METHOD USING SERUM ENRICHED WITH LIPOPROTEIN OR DILUTED Purified low-density lipoprotein was added to two different sera in amounts calculated to increase the serum lipoprotein concentration of each serum by $500,1,000$, and $1,500 \mathrm{mg} . / 100 \mathrm{ml}$. Following assay, by the standard technique, of the enriched and unenriched serum samples, the optical density for each enriched

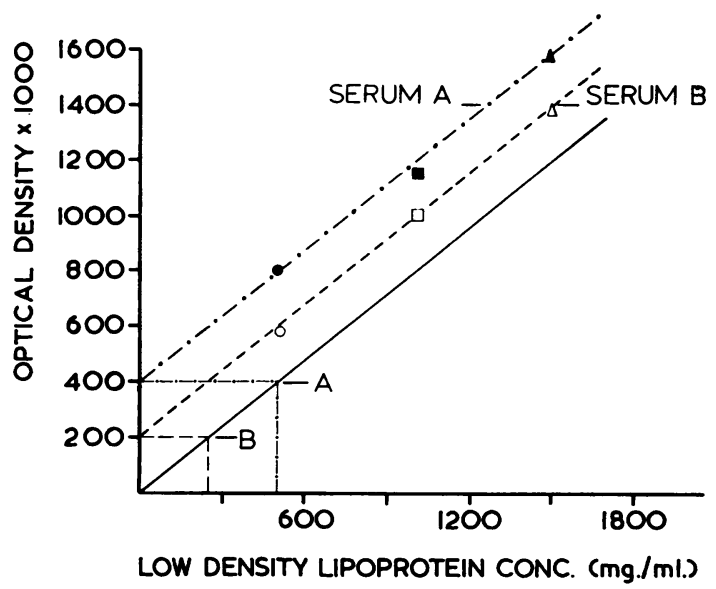

FIG. 5. Verification of assay procedure using serum enriched with lipoprotein at known concentrations. Solid symbols $=$ normal serum $A ;$ open symbols $=$ normal serum $B . \bigcirc=5 \mathrm{mg} . / \mathrm{ml}$., $\square=10 \mathrm{mg} . / \mathrm{ml} ., \Delta \Delta=$ $15 \mathrm{mg} . / \mathrm{ml}$., lipoprotein added to sera $A$ and $B$.

Note parallelism of slopes for enriched sera (interrupted lines) with calculated regression previously obtained (continuous line). Extrapolated values $A^{1}$ and $B^{1}$, obtained as shown, agreed closely with values obtained by direct assay of these sera.

serum was plotted against the expected lipoprotein concentration. A straight line relationship was found for the plotted values for each enriched serum and the lines so drawn, when extrapolated, crossed the ordinate at points giving optical density measurements ( $A^{1}$ and $B^{1}$, see Fig. 5) which agreed, within 
$10 \%$, with the optical density given by the corresponding unenriched serum sample estimated directly. The parallelism between the slopes for the enriched serum samples and the calculated regression for purified low-density lipoprotein, together with the close agreement between the extrapolated values and those obtained by direct assay, suggested that the low-density lipoprotein in serum behaved identically with isolated low-density lipoprotein. These observations also suggested that substances other than the low-density lipoprotein did not contribute appreciably to the turbidity produced under these conditions by dextran sulphate (cf. Bernfeld, Berkowitz, and Donahue, 1957).

When dilution of serum was effected by using $4.4 \mathrm{ml}$. buffer and $0.1 \mathrm{ml}$. serum, the optical density readings obtained corresponded to low-density lipoprotein levels lying consistently within the range of $50 \pm 8 \%$ of the result for the same sera undiluted. This applied only over the range of greatest accuracy of the spectrophotometer, i.e., for serum samples which when assayed undiluted gave optical density readings between $0 \cdot 1$ and $1 \cdot 0$. Beyond this range the correlation was $50 \times 17 \%$.

SPECIFICITY OF ASSAY METHOD IN RELATION TO OTHER SERUM PROTEINS. Immunological assay of the precipitate from four sera (ranging in low-density lipoprotein content from 300 to $1,500 \mathrm{mg} . / 100 \mathrm{ml}$.) revealed only traces of albumin, $\gamma$-globulin, or siderophilin. The low-density lipoprotein-dextran sulphate complex varies in solubility with the ionic strength of the environment. On stirring the precipitate in $2 \mathrm{M}$ sodium chloride the complex dissociates but re-forms on subsequent dilution with $0.02 \mathrm{M}$ calcium acetate and can be recovered by centrifugation. On repeating this process twice, the washed lipoprotein was found to be freed from detectable albumin, $\gamma$-globulin, or other serum proteins. These findings suggested that the initial 'contamination' of the lipoprotein precipitate was due to the entrainment of other serum proteins in the crude precipitate rather than their specific precipitation by dextran sulphate.

On the addition of ${ }^{131}$ I-labelled human albumin to serum and subsequent treatment of the serum with dextran sulphate under the conditions described, only 5 to $7 \%$ of the ${ }^{131} \mathrm{I}$ label was detectable in the initial precipitate.

The dextran sulphate method was also applied to the serum from a case of congenital deficiency of low-density lipoprotein (Salt, Wolff, Lloyd, Fosbrooke, Cameron, and Hubble, 1960). This patient's serum was known to contain $22 \mathrm{mg}$. $/ 100 \mathrm{ml}$. of cholesterol. Low-density lipoproteins were undetectable by paper electrophoresis or ultra- centrifugally and found to be below the limit of $\frac{\mathrm{O}}{\mathrm{a}}$ sensitivity of a gel-diffusion precipitin assay method $\overrightarrow{\vec{D}}$ (Soothill, 1962). The dextran sulphate method $\frac{0}{0}$ applied to this serum gave a turbidity equivalent to a low-density lipoprotein level of $20 \mathrm{mg} . / 100 \mathrm{ml}$. as compared with a normal value of about $400 \mathrm{mg} . / 100$ $\mathrm{ml}$. at this age.

These findings were therefore interpreted as showing that very little precipitation of serum $\vec{\circ}$ proteins other than low-density lipoproteins occurred $\overrightarrow{\vec{H}}$ under the conditions described.

SPECIFICITY OF THE ASSAY METHOD IN RELATION TO PROTEIN-BOUND SERUM LIPIDS

Yield of low-density lipoprotein Immuno-assay of the supernatant after treatment of serum with $\mathrm{N}$ dextran sulphate indicated that over a range of serum low-density lipoprotein levels of 400 to $\frac{}{5}$ $950 \mathrm{mg} . / 100 \mathrm{ml}$., between 90 and $95 \%$ of the low- $\vec{z}$ density lipoprotein was removed by the dextran sulphate interaction.

The low-density lipoproteins from patients with $\frac{3}{0}$

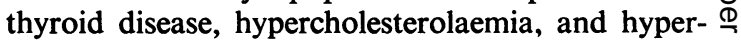
lipaemia were isolated, labelled with ${ }^{131} \mathbf{I}$, and $\vec{\bullet}$ re-infused during the course of studies on the turn- $\stackrel{\oplus}{\perp}$ over of these proteins (Scott, 1962; Scott, Dykes, Davies, and Walton, 1963). Sera withdrawn during the course of these studies and containing ${ }^{131} \mathrm{I}$ labelled low-density lipoprotein were treated with $\overline{0}$ dextran sulphate under the standard assay condi- $\frac{\mathscr{Q}}{\Phi}$ tions but using larger volumes. The precipitate was removed by centrifugation and the radioactivity in $\overrightarrow{\overrightarrow{0}}$ the supernatant counted. The results showed that 85 to $95 \%$ of the radioactivity was removed in the precipitate despite wide variations in the total lowdensity lipoprotein concentration in the initial sera and also wide variation in the relative distribution of $S_{\mathrm{f}}$ classes between sera.

Moreover, when the distribution of the ${ }^{131}$ I-label among the $S_{f}$ classes in the dextran sulphateprecipitated lipoprotein was checked by ultra- $O$ centrifugal analysis, the radioactive label was found to be distributed in proportion to the $S_{\mathrm{f}}$ distribution in individual sera (Scott, 1962; Walton, Scott, Verrier Jones, Fletcher, and Whitehead, 1963). Oั

Relative contributions of $S_{\mathrm{f}}$ classes to dextran N sulphate reaction When the minimum amount of dextran sulphate necessary to produce complete ${ }_{\sigma}^{\omega}$ precipitation of fractions containing different $\mathrm{S}_{\mathrm{f}} \rightleftharpoons$ classes of lipoproteins was investigated, in confirm- $\stackrel{\varrho}{c}$ ation of the findings of Antoniades, Tullis, Sargeant, Pennell, and Oncley (1958), it was found that a somewhat greater concentration of dextran sulphate was necessary fully to precipitate a given concentra- $\frac{\vec{D}}{\mathbb{D}}$ tion of $S_{p} 20-400$ lipoproteins than was necessary for $\frac{\Omega}{\overparen{D}}$ the same concentration of $S_{f} 3-9$ lipoproteins. 
In the standardized dextran sulphate procedure, as previously mentioned, dextran sulphate is deliberately used at a concentration in excess of the minimum required to allow for a margin of error. That this concentration also ensures precipitation of low-density lipoproteins over the whole spectrum of $\mathrm{S}_{\mathrm{f}}$ classes was verified in the following manner.

Sera containing ${ }^{131}$ I-labelled low-density lipoprotein were fractionated in a saline density gradient in the ultracentrifuge to yield fractions corresponding to $S_{\mathrm{f}} 3-9, S_{\mathrm{f}} 10-20$, and $S_{\mathrm{f}} 20-400$. Samples from each fraction were treated with dextran sulphate by the standard procedure. In each case, $90-95 \%$ precipitation was achieved as judged by counting residual radioactivity in the supernatants.

Although it had thus been ensured that all $S_{\mathfrak{f}}$ classes participated in the precipitate, it was not to be expected that the various $S_{f}$ classes would contribute equally to the turbidity produced. The high $\mathrm{S}_{\mathrm{f}}$ classes of the low-density lipoproteins contain relatively large proportions of lipid and particularly of triglyceride and are of greater molecular size than the low $S_{\mathrm{f}}$ lipoproteins. They might therefore be expected to produce more scattering of light and consequently, more turbidity. For example, pathological sera in which $\mathrm{S}_{\mathrm{f}}$ 20-400 lipoproteins greatly predominate, as, for example, in idiopathic hyperlipaemia and certain cases of diabetes or the nephrotic syndrome, usually show a greatly increased intrinsic turbidity and may be quite milky in appearance. It appeared, therefore, of importance to evaluate the contribution made, in terms of turbidity, by the various $S_{\mathrm{f}}$ classes to the dextran sulphate method. A comparison of this kind suggested that fractions consisting of $\mathrm{S}_{\mathrm{f}}$ 3-9 lipoproteins and $S_{\mathrm{f}} 10-20$ lipoproteins contributed approximately equally to the turbidity while the $\mathrm{S}_{\mathrm{f}}$ 20-400 fraction contributed more turbidity than the fractions containing lower $S_{f}$ classes. This result was in keeping with the observation that assays by the dextran sulphate method on sera in which the $\mathrm{S}_{\mathrm{f}} 20-400$ class predominated did not correlate as closely with ultracentrifugal estimations as those for normal sera or for sera with overall elevation of low-density lipoproteins but with a normal $S_{\mathbf{f}}$ distribution (see below).

Contribution of chylomicra It has been suggested that the small amount of protein associated with the chylomicra may be derived by adsorption of both low- and high-density $\left(a_{1}-\right)$ lipoproteins on to the lipid of the chylomicra (Scanu and Page, 1959).

In experiments using suspensions of isolated and washed chylomicra and also in comparisons made between serum samples from which chylomicra had been removed by preliminary centrifugation and serum samples not so treated, it was found that chylomicra could contribute a small error to assays of low-density lipoproteins by the dextran sulphate method. The correction applied for inherent turbidity of the serum (see technique adopted for standard method) was adequate in all but the most turbid serum specimens, in which it seemed probable that to some extent chylomicra were occluded in the precipitate. In extended clinical use the error introduced by the contribution of chylomicra has not proved to be of major importance.

High-density lipoproteins Immunological investigation by gel-diffusion methods showed the presence, occasionally, of traces of high-density lipoproteins in the crude dextran sulphate precipitate from whole serum but these were removed on washing the precipitate and hence were judged to be due to occlusion in the precipitate. Purified high-density lipoprotein was not precipitated by dextran sulphate.

INVESTIGATION OF THE ERROR OF THE METHOD AsSays in duplicate on 30 separate serum specimens were carried out independently by two observers. Calculation of the standard deviation from the mean for each observer gave values of $21.3 \mathrm{mg}$. $/ 100 \mathrm{ml}$. for one observer and $15.4 \mathrm{mg} . / 100 \mathrm{ml}$. for the other.

On carrying out an analysis of variance on the readings produced by each observer on the same

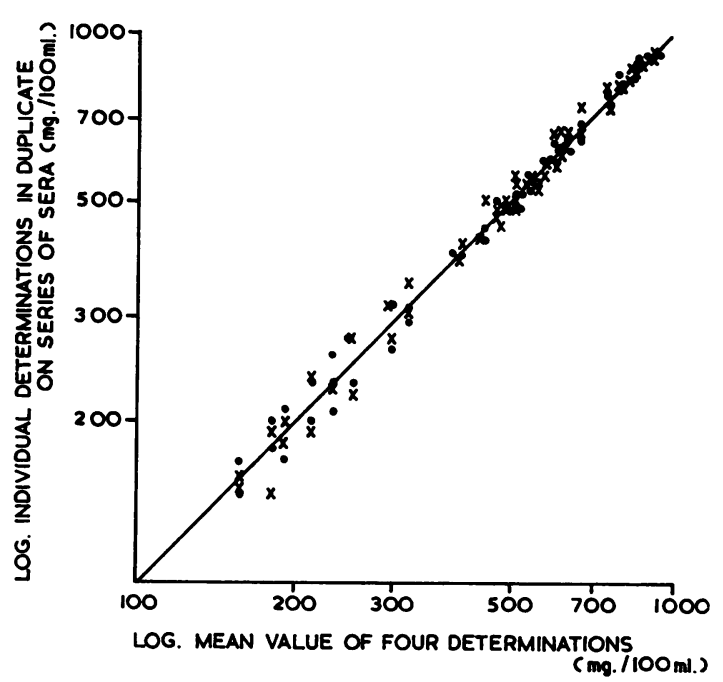

FIG. 6. Duplicate readings for low-density lipoprotein assays on a series of serum samples carried out by two observers. The readings are plotted on logarithmic axes against the mean value for each serum specimen $\left(45^{\circ}\right.$ slope). $\mathrm{O}=$ determinations by observer $A ; O=$ determinations by observer $B$. Note that the points lie closer to the mean at high serum low-density lipoprotein levels, suggesting that the error of the method is fixed rather than proportional to the lipoprotein concentration. 
serum specimens it was found that the mean difference between observers was $6.7 \mathrm{mg} . / 100 \mathrm{ml}$. on an overall mean figure of $521 \mathrm{mg} . / 100 \mathrm{ml}$. (This difference, though small, was significant at the $1 \%$ level.) No significant difference was encountered between the first and second readings for either observer. The standard deviation for the two observers (allowing for intra-observer error) was $17 \cdot 1 \mathrm{mg}$. $/ 100 \mathrm{ml}$. It was concluded that each observer was able to undertake the measurements with a degree of accuracy of $\pm 9 \%$ of the average normal serum concentration of lowdensity lipoprotein and this was regarded as acceptable.

On plotting the duplicate readings for low-density lipoprotein concentration for the serum specimens by both observers against the mean value for each specimen on logarithmic axes (Fig. 6) it can be seen that the points lay closer to the slope for the mean at high lipoprotein levels, indicating that the error of the method was fixed rather than varying with the lipoprotein concentration. In other words, it appeared advisable to quote the error of this method in terms of a fixed deviation of $\pm 35 \mathrm{mg} . / 100 \mathrm{ml}$. rather than as a percentage of the derived serum value.

Multiple assays on the same serum samples gave a maximum range of deviation of $40 \mathrm{mg}$. $/ 100 \mathrm{ml}$. about the mean with a standard deviation of $18 \mathrm{mg}$. $/ 100 \mathrm{ml}$.

\section{COMPARISON OF DEXTRAN SULPHATE METHOD WITH OTHER ASSAY TECHNIQUES}

WITH ULTRACENTRIFUGAL ESTIMATES Seventy-six parallel estimations of low-density lipoproteins

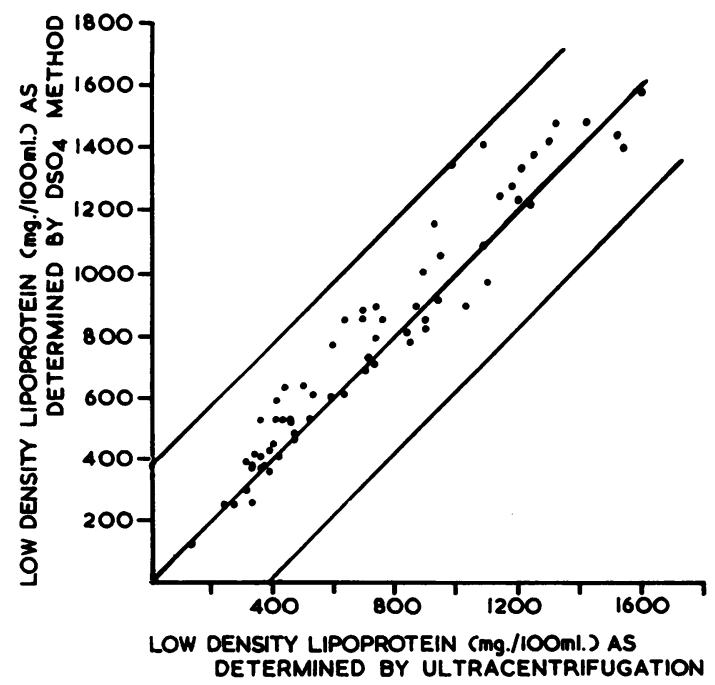

FIG. 7. Correlation between determinations of low-density lipoproteins by the dextran sulphate method and by ultracentrifugation, showing scatter in relation to the regression and to calculated $95 \%$ confidence limits. were carried out on the same serum samples by a density-gradient ultracentrifuge technique essentially similar to that of Havel et al. (1955) and by the $\overline{0}$ dextran sulphate method. The data, when treated as $\bar{c}$ grouped frequency distributions and analysed with the ultracentrifugal estimates assumed to be the independent variable, gave a correlation coefficient (r) of 0.972 (significance $>0.001$ ). The scatter, in relation to the theoretical regression coefficient, and $\vec{\circ}$ to the calculated $95 \%$ confidence limits, is shown in Figure 7.

This correlation was regarded as adequate for the 용 designed purpose of the dextran sulphate method.

WITH PAPER ELECTROPHORESIS Sixty-eight parallel estimations of low-density lipoproteins were carried $\mathrm{N}$ out on the same serum samples by the paper electrophoresis method of Salt and Wolff (1957) and by the dextran sulphate method. The results, similarly treated and analysed with the paper electrophoretic method assumed to be the independent variable, gave a correlation coefficient $(r)$ of 0.896 (significance $>0.001)$. The scatter in relation to the theoretical slope and calculated confidence limits is shown in Figure 8.

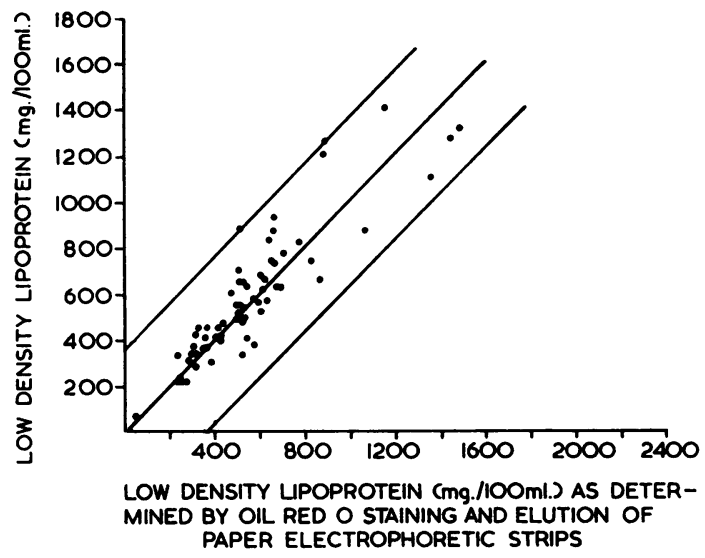

FIG. 8. Correlation between determinations of low-density lipoproteins by the dextran sulphate method and by paper o electrophoresis (method of Salt and Wolff, 1957) showing $N$ scatter in relation to the regression and to calculated $95 \%$ confidence limits.

The range of deviation, in this case, was greater $\stackrel{0}{\frac{0}{D}}$ and the correlation less close, than in the case of the $\stackrel{?}{?}$ comparison with the ultracentrifugal estimates, 0 presumably because of the larger error in the paper $\bar{D}$ electrophoretic method. The correlation with paper $\mathbb{D}$ electrophoretic estimation was nevertheless regarded as acceptable. 
WITH IMMUNOLOGICAL ESTIMATES Eleven comparisons were made between estimates by the dextran sulphate method and assays by the gel-diffusion precipitin method of Soothill (1962). In the latter method, results are expressed in terms of percentage of a 'normal control' serum. To provide a basis for the comparison of results. six determinations by the dextran sulphate method were carried on the 'normal control' serum and values obtained for the test sera corrected proportionately.

The numbers tested were regarded as too small for detailed analysis but it was observed that the range of deviation of the dextran sulphate method in terms of the immunological assay was +44 to $-89 \%$ with a mean deviation of $-19.6 \%$. Since the coefficient of variation for the immunological estimation itself is $\pm 14 \%$ (Soothill, 1962), its agreement with the dextran sulphate method was regarded as less satisfactory than that obtained in the other comparisons above.

A few comparisons were also made between the 'immunocrit' method of Heiskell et al. (1961) and the dextran sulphate method. Since this immunological method as available commercially only detects 'low', 'normal', and 'high' levels of low- density lipoproteins, no detailed comparison was undertaken.

APPLICATION OF METHOD FOR POPULATION SURVEYS

DISTRIBUTION OF SERUM LEVELS IN A MIDLANDS POPULATION The main population sample totalled 507 individuals. Of these, 12 were infants under 1 year for whom the results were grouped regardless of sex. The remainder comprised 290 males and 205 females ranging in age from 1 year to the seventh decade.

An overall analysis of distribution of serum low density lipoprotein levels, disregarding age and sex differences, showed a fairly pronounced departure from a normal distribution, the mode being displaced to the left of the mean (Fig. 9A). On replotting frequencies against the logarithms of the serum lipoprotein levels, the histogram obtained approximated more closely to the calculated normal distribution curve (Fig. 9B), with closer correspondence between the mode and mean.

Distribution in relation to sex Separate analyses of distribution of serum levels in males and females gave essentially similar results to those obtained

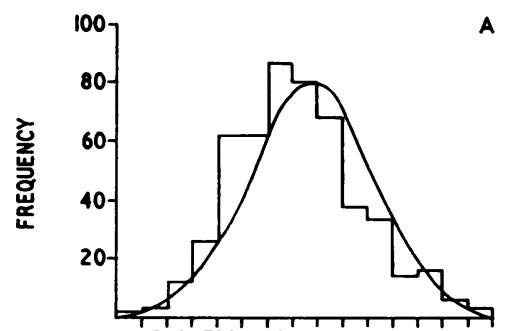

$200^{\prime} 300^{\prime} 400^{\prime} 500^{\prime} 600^{\prime} 700^{\prime} 800$ CONCENTRATION OF SERUM
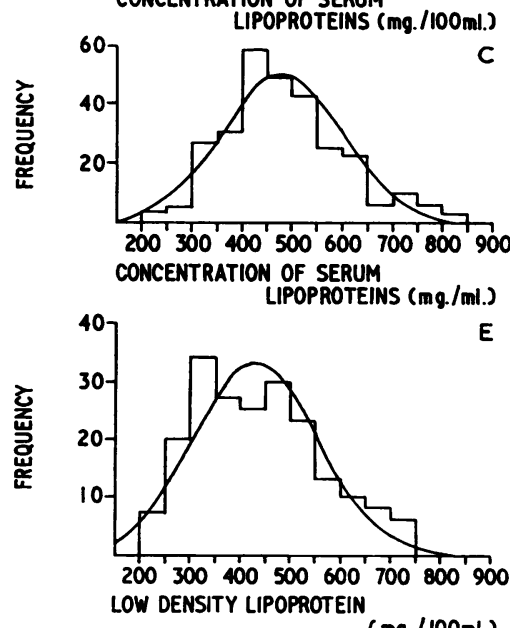

A

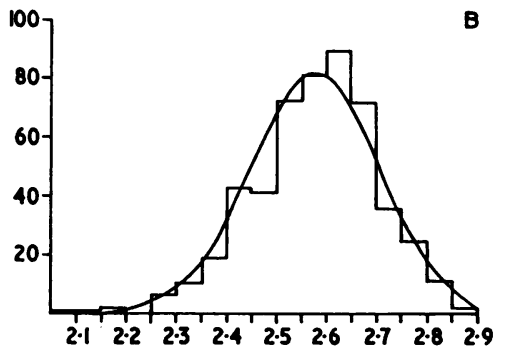

LOG. CONCENTRATION SERUM LIPOPROTEIN
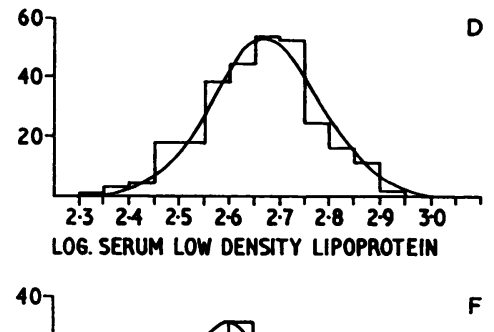

FIG. 9. Histograms of frequency distribution of serum low-density lipoprotein levels; $A$, frequency distribution of overall population examined, disregarding age and sex (arithmetic plot); $B$, same population (logarithmic plot); $C$, frequency distribution in males (arithmetic plot); $D$, males (geometric plot); $E$, females (arithmetic plot), $F$, females (geometric plot). In each case the theoretical normal distribution curve for the data is superimposed. 
above, the arithmetic plot giving histograms in which the mode was displaced to the left of the mean, the logarithmic plot histograms conforming more closely to the theoretical normal distribution curve (Fig. 9C and D; E and F).

Formal analysis of the data for symmetry confirmed these findings. It can be seen from Table I that the arithmetic normal distribution, when tested in each case, gave values for $\mathrm{g}_{1}$ (a term measuring skewness) which were positive and significantly different from zero, confirming the asymmetry due to positive skewing. On the other hand, the values obtained for $\mathrm{g}_{2}$ (a term measuring kurtosis, a departure encountered in otherwise symmetrical sets of data and characterized by either an excess or a deficit of items concentrated near the centre of the range) were negative, indicating some excess of moderate deviations from the mean, i.e., flat-topped distribution curves, as would be expected from the shapes of the histograms (see Fig. 9). The values of $\mathrm{g}_{2}$ were in no case significant, however.

It can also be seen from Table I that on testing the logarithmic normal distributions, the values obtained for $g_{1}$ decreased to non-significant levels, the negative values for this term for the data for males and for the overall population, suggesting, in fact some over-correction, with slight, but not significant negative skewing which is borne out by the appearance of Figures $9 B$ and D. It was also noteworthy that the values for $\mathrm{g}_{2}$, while remaining non-significant, changed in sign indicating a slight departure of the opposite kind, namely, an excess of items near the mean and far from it with corresponding depletion of the flanks of the distribution.

These observations were taken to signify that the serum low-density lipoproteins in a normal popula- tion conform to a logarithmic normal rather than a normal distribution. From this it follows that means $\vec{F}$ should be expressed as geometric rather than as arithmetic means and that standard errors and standard deviations should be presented as asymmetrically distributed about the means (as shown in columns 4 and 5 of Table I). AND allow comparisons between $(a)$ assays of low-density lipoprotein levels by the dextran sulphate method and serum cholesterol levels determined by the method of Henly (1957) in the Biochemical Depart- $\vec{V}$ ment of the Queen Elizabeth Hospital, Birmingham; and (b) assays of low density lipoproteins levels by the dextran sulphate method and cholesterol $\mathrm{V}$ estimations by the method of Crockson (1962) 윽 carried out in the Department of Experimental Pathology, University of Birmingham.

A preliminary investigation showed a satisfactory correlation between cholesterol determinations 3 carried out by these two different techniques (Fig. 음 10). The cholesterol data were therefore pooled and plotted against the serum lipoprotein levels as shown in Figure 11. The correlation coefficient obtained : was $r=0.94$ (significance $>0.001$ ), which was regarded as satisfactory in the light of the known coefficients of variation for the techniques used.

It will be observed that the regression line in Fig. 11 crosses the abscissa to the right of the origin. $\stackrel{\mathbb{Q}}{\varrho}$ This is because 60 to $80 \mathrm{mg} . / 100 \mathrm{ml}$. of the normal $\overrightarrow{\vec{D}}$ total serum cholesterol is associated with a separate $\frac{3}{3}$ protein fraction (the high-density, or $\alpha_{1}$-lipoproteins).

In confirmation of a previous observation? (Wootton and King, 1953) it was found that total serum cholesterols also conformed to a logarithmic?

TABLE I

TESTS OF SYMMETRY OF NORMAL AND LOG-NORMAL DISTRIBUTIONS OF LOW-DENSITY LIPOPROTEIN LEVELS

\begin{tabular}{|c|c|c|c|c|c|c|c|c|c|c|}
\hline \multirow[b]{2}{*}{$\begin{array}{l}\text { Population } \\
\text { Sample }\end{array}$} & \multirow[b]{2}{*}{$\begin{array}{l}\text { Distribution } \\
\text { Tested }\end{array}$} & \multirow[b]{2}{*}{$\begin{array}{l}\text { Mean } \\
(\mathrm{mg} .1 \\
100 \mathrm{ml} .)\end{array}$} & \multicolumn{6}{|c|}{ LIPOPROTEIN LEVELS } & \multirow[b]{2}{*}{${ }^{3} t$} & \multirow[b]{2}{*}{ Significance } \\
\hline & & & $\begin{array}{l}\text { S.E. of } \\
\text { Mean } \\
(\mathrm{mg.l} \\
100 \mathrm{ml} .)\end{array}$ & $\begin{array}{l}\text { Standard } \\
\text { Deviation } \\
(\mathrm{mg} . / \\
100 \mathrm{ml} .)\end{array}$ & $g_{1}$ & ${ }^{3} t$ & Significance & $g_{2}$ & & \\
\hline \multirow[t]{2}{*}{290 males } & $\begin{array}{l}\text { Arithmetic } \\
\text { Normal }\end{array}$ & $488 \cdot 1^{1}$ & \pm 6.87 & \pm 116.9 & 0.5192 & $3 \cdot 63$ & $>0.001$ & $-0 \cdot 2176$ & 0.763 & $>0.5 ;<0.4$ \\
\hline & Log-normal & $473 \cdot 6^{2}$ & $\begin{array}{l}+7 \cdot 1 \\
-7 \cdot 0\end{array}$ & $\begin{array}{l}+136 \cdot 8 \\
-106 \cdot 2\end{array}$ & -0.2122 & $1 \cdot 49$ & $>0.2 ;<0.1$ & 0.0006 & 0.002 & $<0.5$ \\
\hline \multirow[t]{2}{*}{205 females } & $\begin{array}{l}\text { Arithmetic } \\
\text { Normal }\end{array}$ & $436 \cdot 0^{1}$ & \pm 8.67 & $\pm 123 \cdot 8$ & 0.4429 & $2 \cdot 61$ & $>0.01 ;<0.005$ & -0.4758 & $1 \cdot 25$ & $>0.4 ;<0.2$ \\
\hline & Log-normal & $394 \cdot 9^{2}$ & $\begin{array}{l}+5 \cdot 1 \\
-5 \cdot 0\end{array}$ & $\begin{array}{r}+119 \cdot 1 \\
-91 \cdot 5\end{array}$ & $0 \cdot 1200$ & $0 \cdot 70$ & $>0.5 ;<0.4$ & 0.4152 & $1 \cdot 23$ & $>0.4 ;<0.2$ \\
\hline \multirow{3}{*}{$\begin{array}{l}\text { Overall } \\
\text { population } 507 \\
\text { males, females, } \\
\text { infants }\end{array}$} & $\begin{array}{l}\text { Arithmetic } \\
\text { Normal }\end{array}$ & $459 \cdot 8^{1}$ & $\pm 17 \cdot 8$ & $\pm 126 \cdot 8$ & 0.3329 & 3.07 & $>0.005$ & -0.0623 & $-0 \cdot 26$ & $<0.50$ \\
\hline & Log-Aormal & $424 \cdot 1^{2}$ & $\begin{array}{l}+17 \cdot 8 \\
-17 \cdot 7\end{array}$ & $\begin{array}{l}+142 \cdot 5 \\
-106 \cdot 5\end{array}$ & $-0 \cdot 2230$ & $2 \cdot 05$ & $>0.05<0.025$ & 0.5218 & $2 \cdot 425$ & $>0.025<0.01$ \\
\hline & \multicolumn{3}{|c|}{${ }^{1}=$ arithmetic mean; } & ${ }^{2}=$ geon & hetric mean & & ${ }^{3} \mathrm{t}$ for d.f. $=\alpha$ & inity) & & \\
\hline
\end{tabular}




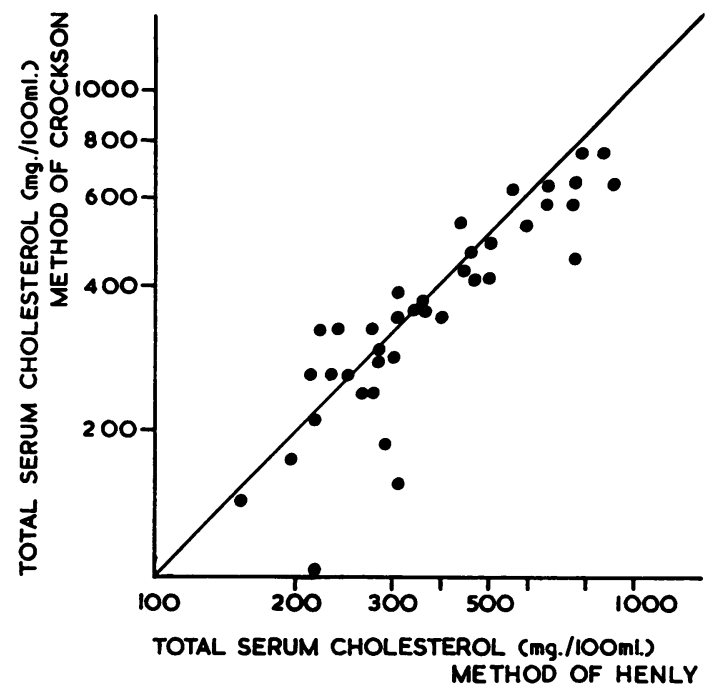

FIG. 10 Correlation between serum cholesterol estimations carried out by method of Henly (1957) and by method of Crockson (1962).

- METHOD OF HENLY

O METHOD OF CROCKSON

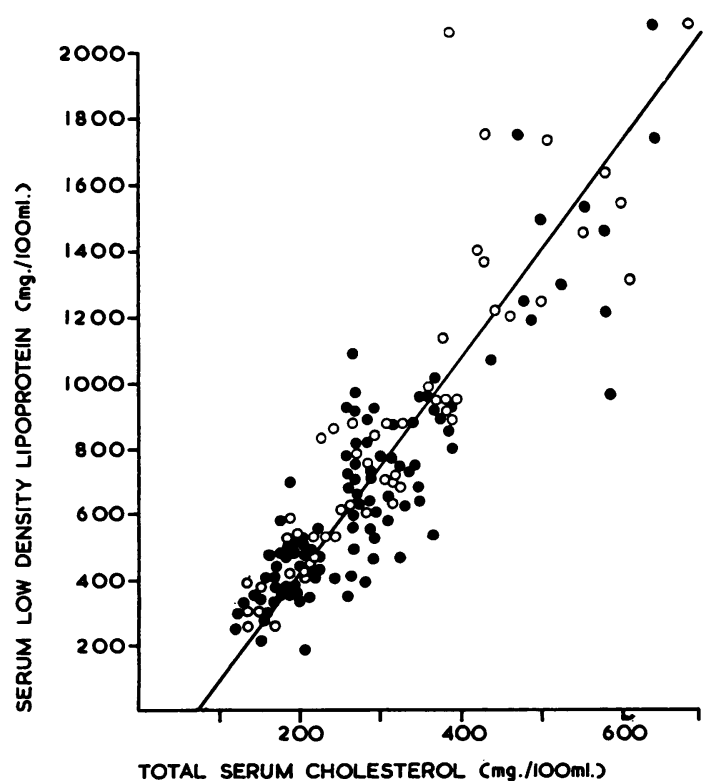

FIG. 11. Correlation, between total serum cholesterol estimations and serum low-density lipoprotein determinations. : Cholesterol by method of Henly (1957); $\bigcirc$ : cholesterol by method of Crockson (1962). Note that regression line intersects abscissa to the right of the origin. This is because $60-80 \mathrm{mg} . / 100 \mathrm{ml}$. of the total serum cholesterol is associated with another serum protein (high-density lipoprotein). normal distribution. The satisfactory correlation nevertheless obtained between cholesterol and lowdensity lipoprotein levels suggested that even the fluctuations in level of the total serum cholesterol in normal individuals in a given population must be determined predominantly by corresponding fluctuations in level of the major cholesterol-carrying fraction of the serum, the low-density lipoproteins. It has been observed repeatedly in disease states (cf. Oncley and Gurd, 1953; Lindgren and Nichols, 1960) that major alterations in level of serum cholesterol are almost always associated with alterations in level of the low-density lipoproteins and that the high-density lipoproteins show relatively little change.

Recalculation of the data presented by Page, Kirk, Lewis, Thompson, and Van Slyke (1935) for phospholipids and plasma neutral fats in normal individuals also revealed a logarithmic normal distribution and since these components, too, are carried in part by low-density lipoproteins, it seems likely that similar considerations to the above may apply here again.

EFFECT OF OCCUPATION ON SERUM LIPOPROTEIN LEVELS While an attempt was made to avoid bias in the compilation of the overall population group studied and reported above, it was clear that figures derived from the sources indicated were somewhat weighted in favour of persons in sedentary occupations. It has been shown that mortality rates from ischaemic heart disease may differ significantly with the amount of exercise entailed in various occupations (cf. Morris, Heady, Raffle, Roberts, and Parks, 1953). In view of the significant correlation which has been claimed between the incidence of atherosclerosis and lipoprotein levels, it appeared advisable to make a comparison with an occupationally different population sample. Accordingly, surplus serum obtained from an unselected group of blood donors aged 20 to 45 years (mostly factory employees, some of whom were undertaking heavy manual work) was analysed and the results compared with those previously obtained in a similar age group (Table II).

Since this population sample was relatively small, comparison was made on the basis of the more usual procedure which assumes a normal distribution and calculates arithmetic means and symmetrical standard deviations.

It will be observed that no significant difference could be shown between the values obtained for the individuals in this restricted sample and those in the corresponding age range in the overall population sample previously examined.

It will be noted that in the above instance, the population samples were matched in age and sex. 
TABLE II

COMPARISON OF LOW-DENSITY LIPOPROTEIN LEVELS OF A SELECTED GROUP (BLOOD DONORS) WITH OVERALL POPULATION SAMPLES

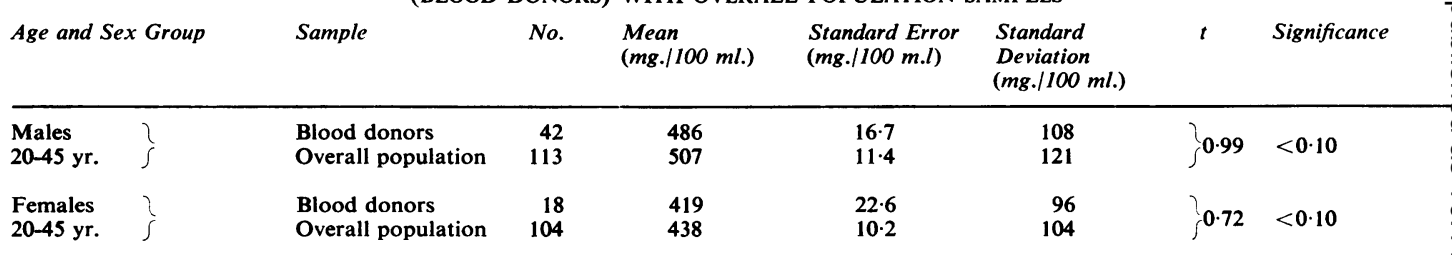

This was found to be necessary because of the following findings in the main population sample:-

VARIATION OF MEAN LIPOPROTEIN LEVELS WITH AGE AND SEX Comparison of the mean values for each decade showed marked differences in trend between sexes in adults. It can be seen from Fig. 12 that no significant difference was detectable in the mean values for boys and girls up to the age of 12. After this, a rapid divergence was observed in the 'teens,' the mean values for boys and young men rising sharply and then levelling off in the third decade to form a more gently ascending plateau which finally declined gently again from the sixth decade onward. The mean values for girls and young women, on the other hand, mounted more gradually with age throughout the normal life span. In the middle of the sixth decade, the curves for each sex were observed to intersect with mean values for females actually exceeding those for males beyond the age of 55 or so.

We have been unable to find figures for a systematic survey of low-density lipoprotein levels in normal children with which to compare our results but a comparison with the figures of Salt and Wolff

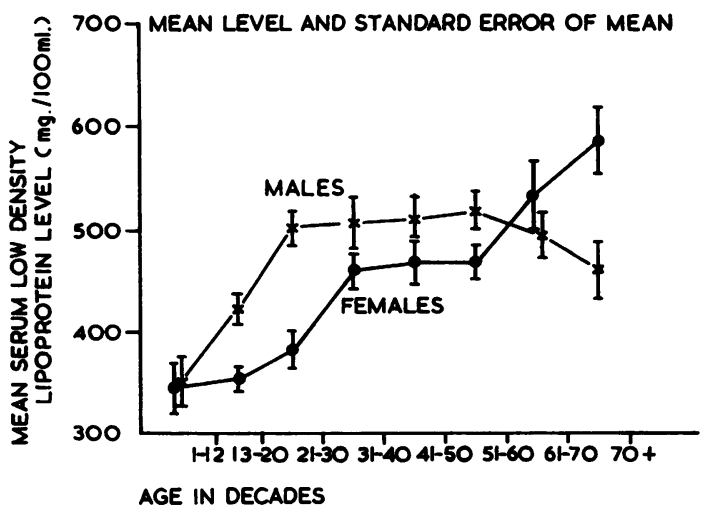

FIG. 12. Variation of mean serum low-density lipoprotein levels with age and sex. $\mathbf{X}$ : Mean level and standard error of mean, males; $\bar{I}$ : mean level and standard error of mean, females.
(1957) for a limited number of normal children, is set out in Table IV. Figures derived from ultrae centrifugal studies published by Glazier, Tamplin $\overrightarrow{\vec{N}}$ Strisower, DeLalla, Gofman, Dawber, and Phillipș (1954) have been replotted for the age groups from? 11 to 20 onwards, in decades for comparison with ours (Fig. 13, also see Table III).

These figures were derived from North American populations possibly differing in living standards an dietetic habits from ours, and were obtained by different method (calculated from analytical ultraב̄ centrifugal data). Although the mean values fo each age group beyond the third decade differ from ours, similar trends are unmistakable in thळ general shapes and directions of the curves and $a$ similar divergence between the graphs for the sexes is apparent.

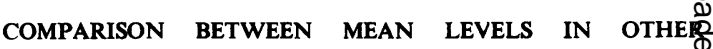
POPULATION SAMPLES It has apparently not beea appreciated previously that serum low-densit $\overrightarrow{\mathscr{B}}$ lipoproteins conform to a logarithmic norma distribution, data previously published having assumed a normal distribution. In spite of the observations already presented which appear to

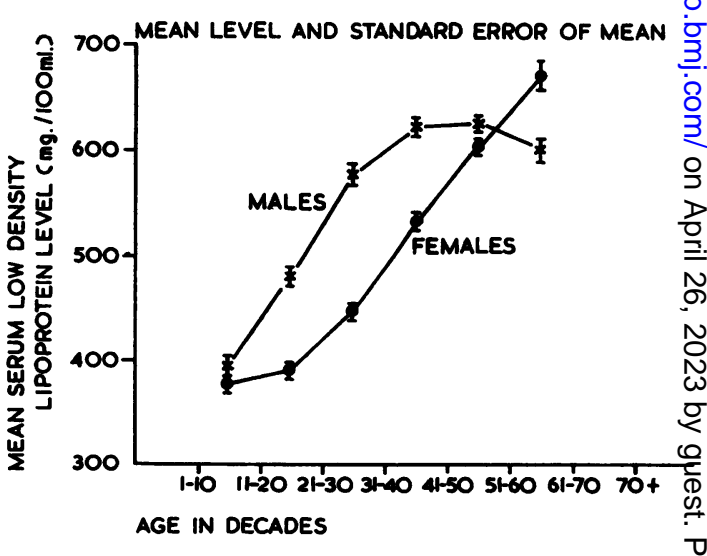

FIG. 13. Data of Glazier et al. (1954) replotted (see text $\Phi$ for comparison with Figure 4. $\overline{\text { 1: }}$ Mean level and standarg error of mean, males; $\Phi$ : mean level and standard erro of mean, females. 
question the latter assumption, in order to allow comparison of our results with the data in the literature, in this and succeeding sections of this paper, we have reverted to the practice of calculating means, standard errors of means and standard deviations on the basis of a normal distribution.

It is possible that significant differences in lowdensity lipoprotein levels may also be found between economically and geographically distinct populations (cf. Keys and Grande, 1957) and that the distribution curves for these may show different degrees of skewing. When this consideration is added to differences which may arise from diversity in the techniques adopted for the estimation of the lowdensity lipoproteins, it is clear that no satisfactory basis for comparison exists and that only general agreement is to be expected.

This is perhaps exemplified by Tables III and IV in

\section{TABLE III}

COMPARISON OF VARIATIONS IN SERUM LOW-DENSITY LIPOPROTEINS LEVELS WITH AGE AND SEX AS ESTIMATED BY THE DEXTRAN SULPHATE METHOD, ANALYTICAL, ULTRACENTRIFUGATION, AND BY THE AMYLOPECTIN SULPHATE METHOD

\begin{tabular}{|c|c|c|c|c|c|c|c|c|c|c|c|c|c|}
\hline \multirow[t]{2}{*}{ Sex } & \multirow[t]{2}{*}{$\begin{array}{l}\text { Age } \\
\text { Group } \\
(y r .)\end{array}$} & \multicolumn{4}{|c|}{$\begin{array}{l}\text { Dextran Sulphate Method (Walton } \\
\text { et. al. 1963, Birmingham, England) }\end{array}$} & \multicolumn{4}{|c|}{$\begin{array}{l}\text { Analytical Ultracentrifugation } \\
\text { (Glazier et al. 1954, Framingham, Mass } \\
\text { and Berkeley, California, U.S.A.) }\end{array}$} & \multicolumn{4}{|c|}{$\begin{array}{l}\text { Amylopectin Sulphate and Nephelometry } \\
\text { (Bernfeld et al., 1960, Boston, U.S.A.) }\end{array}$} \\
\hline & & No. & $\begin{array}{l}\text { Mean } \\
(\mathrm{mg} \cdot / \\
100 \mathrm{ml} .)\end{array}$ & $\begin{array}{l}\text { S.E. } \\
(\mathrm{mg} . / \\
100 \mathrm{ml} .) \\
\text { of Mean }\end{array}$ & $\begin{array}{l}S . D . \\
(\mathrm{mg} . / \\
100 \mathrm{ml} .)\end{array}$ & No. & $\begin{array}{l}\text { Mean } \\
(\mathrm{mg} . / \\
100 \mathrm{ml} .)\end{array}$ & $\begin{array}{l}\text { S.E. } \\
(\mathrm{mg} . / \\
100 \mathrm{ml} .) \\
\text { of Mean }\end{array}$ & $\begin{array}{l}S . D . \\
(\mathrm{mg} . / \\
100 \mathrm{ml} .)\end{array}$ & No. & $\begin{array}{l}\text { Mean } \\
(\mathrm{mg} . / \\
100 \mathrm{ml} .)\end{array}$ & $\begin{array}{l}\text { S.E. } \\
(\mathrm{mg} . / \\
100 \mathrm{ml} .) \\
\text { of Mean }\end{array}$ & $\begin{array}{l}\text { S.D. } \\
(\mathrm{mg} . \mathrm{l} \\
100 \mathrm{ml} .)\end{array}$ \\
\hline Males & $\begin{array}{l}11-20 \\
21-30 \\
31-40 \\
41-50 \\
51-60 \\
61-70 \\
70+ \\
\text { Total }\end{array}$ & $\begin{array}{r}53 \\
43 \\
30 \\
40 \\
45 \\
39 \\
24 \\
290\end{array}$ & $\begin{array}{l}395 \\
502 \\
507 \\
513 \\
519 \\
495 \\
462 \\
488\end{array}$ & $\begin{array}{r}12 \cdot 2 \\
16 \cdot 8 \\
24 \cdot 5 \\
19 \cdot 3 \\
16 \cdot 9 \\
22 \cdot 3 \\
27 \cdot 8 \\
6 \cdot 9\end{array}$ & $\begin{array}{r}89 \\
110 \\
134 \\
122 \\
113 \\
139 \\
136 \\
117\end{array}$ & $\begin{array}{r}29 \\
75 \\
358 \\
313 \\
228 \\
43\end{array}$ & $\begin{array}{l}395 \\
480 \\
576 \\
622 \\
624 \\
599\end{array}$ & $\begin{array}{l}8 \cdot 9 \\
6 \cdot 7 \\
4 \cdot 3 \\
4 \cdot 4 \\
5 \cdot 4 \\
9 \cdot 7\end{array}$ & $\begin{array}{r}68 \\
83 \\
114 \\
109 \\
115 \\
90\end{array}$ & $\begin{array}{r}25 \\
77 \\
489 \\
294 \\
65\end{array}$ & $\begin{array}{l}651 \\
642 \\
669 \\
704 \\
682\end{array}$ & $\begin{array}{r}7.5 \\
14.4 \\
7 \cdot 3 \\
9.5 \\
9.9 \\
\\
5.3\end{array}$ & $\begin{array}{l}119 \\
126 \\
160 \\
162 \\
196 \\
\\
159\end{array}$ \\
\hline Females & $\begin{array}{l}11-20 \\
21-30 \\
31-40 \\
41-50 \\
51-60 \\
61-70 \\
70+ \\
\text { Total }\end{array}$ & $\begin{array}{r}25 \\
34 \\
38 \\
32 \\
32 \\
22 \\
10 \\
205\end{array}$ & $\begin{array}{l}358 \\
383 \\
460 \\
469 \\
470 \\
535 \\
587 \\
436\end{array}$ & \begin{tabular}{r|}
$13 \cdot 8$ \\
$17 \cdot 5$ \\
$16 \cdot 9$ \\
$21 \cdot 2$ \\
$14 \cdot 3$ \\
$33 \cdot 0$ \\
$31 \cdot 0$ \\
$8 \cdot 7$
\end{tabular} & $\begin{array}{r}69 \\
102 \\
104 \\
120 \\
81 \\
155 \\
98 \\
124\end{array}$ & $\begin{array}{r}32 \\
86 \\
452 \\
399 \\
269 \\
43\end{array}$ & $\begin{array}{l}376 \\
390 \\
447 \\
533 \\
603 \\
670\end{array}$ & $\begin{array}{r}8 \cdot 1 \\
4 \cdot 7 \\
2 \cdot 6 \\
3 \cdot 2 \\
4 \cdot 3 \\
12 \cdot 8\end{array}$ & $\begin{array}{r}65 \\
62 \\
77 \\
89 \\
99 \\
118\end{array}$ & \multicolumn{4}{|c|}{$\begin{array}{l}{ }^{1} \text { Results above from } 893 \text { men and } 49 \\
\text { women presented together but figures } \\
\text { for total male sample and total female } \\
\text { sample considered separately by these } \\
\text { authors. }\end{array}$} \\
\hline
\end{tabular}

TABLE IV

COMPARISON OF PUBLISHED DATA FOR LOW-DENSITY LIPOPROTEIN LEVELS IN HEALTHY INDIVIDUALS WITH MEAN VALUES FOUND IN PRESENT INVESTIGATION

Reference Sample

No. Method Mean Present Investigation (mg./100 ml.) (mg./100 ml.)

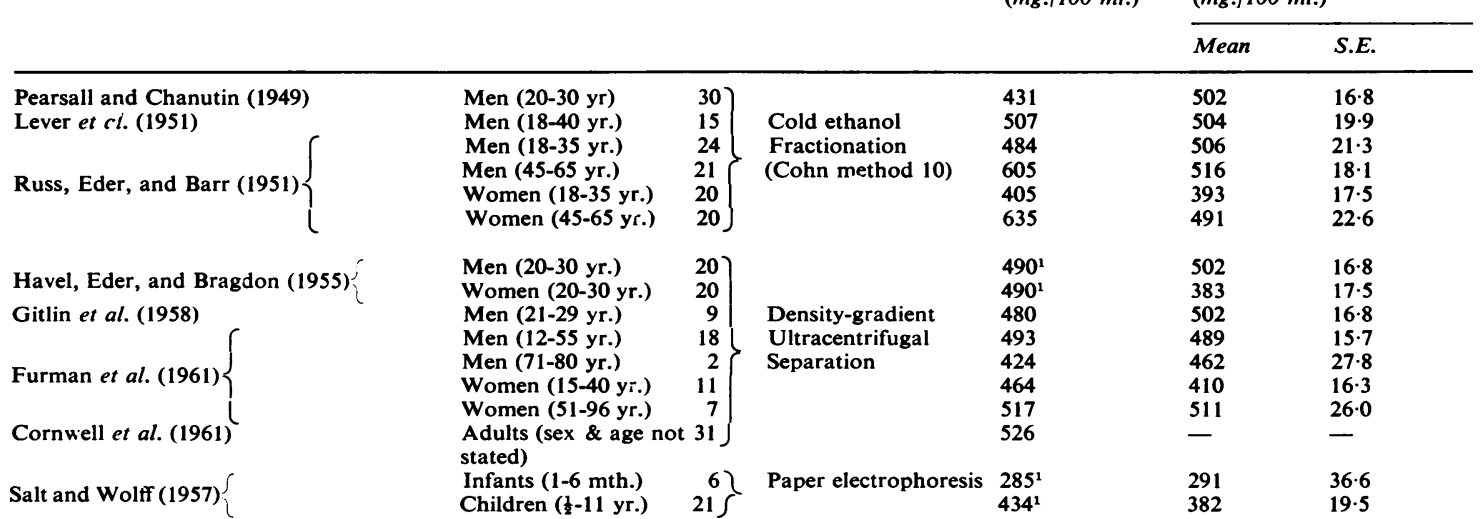

${ }^{1}$ Values for low-density lipoprotein as calculated by authors quoted.

In all other instances, lipoprotein concentrations have been derived from cholesterol content of either Cohn fractions II and III or of ultracentrifugal fraction of density $<1.063 \mathrm{~g} . / \mathrm{ml}$. as described in text. 
which a comparison has been attempted between the present data and those published by several groups of workers, mainly in the United States.

In Table III a comparison has been made with two large population surveys of serum lipoprotein levels. From the data provided by Glazier et al. (1954) values for non-fasting subjects (comprising 2,105 individuals studied by the Framingham Heart Project of the U.S. Public Health Service, and 222 members of the Berkeley University population) have been re-grouped as 'mean standard $\mathrm{S}_{\mathrm{f}} \mathrm{O}-12$ ' plus 'mean standard $\mathrm{S}_{\mathrm{f}} 12-400$ ' lipoprotein levels to give a figure for 'total low-density lipoprotein' and the necessary recalculation of standard errors and standard deviations carried out, in order to make the figures comparable in presentation with our own, in relation to age and sex groupings. Similarly, from the data presented by Bernfeld, Bonner, and Berkeley (1960) for 5-year age groups, values have been re-grouped in decades and the standard errors and standard deviations recalculated. These workers examined a predominantly male population sample and did not analyse results obtained for the small female sample separately from the data for males, apart from a comparison of overall means for males and females.

It will be observed that, in spite of the reservations made above, there is a measure of agreement in trend between the three sets of data, in that all show an increase in mean level with age to the sixth decade and then a decrease. However, there is marked variation between the actual mean levels in the later decades, both these sets of American figures considerably exceeding those presently obtained. Possible reasons for this discrepancy are discussed later.

In Table IV, a comparison is set out simply on the basis of mean levels, for groups matched in age and sex between our data and those in several small population samples presented by other workers. Serum lipoprotein levels have been derived, where shown, from the cholesterol content, either of Cohn fractions II and III, or of fractions of density $<1.063 \mathrm{~g}$. $/ \mathrm{ml}$. obtained by preparative ultracentrifugation in a saline density gradient, by multiplying by the factor 3.29 (obtained from the percentage cholesterol content of the total low-density lipoproteins by Oncley et al., 1957). It will be observe $\overline{\bar{\phi}}$ that, on the whole, the correlation with these figures is much more satisfactory. Possible reasons for the better correlation between our data and those in this second group are also discussed later.

As already shown (see Table II) comparisons of small samples from a geographically homogeneous population correlate adequately, provided the samples are matched for age and sex. It was found that this held good even when observations were made with the dextran sulphate method carried ou by two different observers using different sets of reagents, different batches of dextran sulphate, and different spectrophotometers, at different times. Thg results shown in Table $\mathrm{V}$ compare the levels obtained independently in this way in two successive years fop pre-clinical student groups. It will be seen that the mean values and standard deviations showed acceptable agreement between the two studenf groups.

REPRODUCIBILITY OF OBSERVATIONS IN THE SAME INDIVIDUAL It was found that the range of variatiog encountered in a given individual fell within the coefficient of variation of the method when repeated estimations were made on individuals with a wide range of mean levels, over weeks or months (Fig. 14) As Fig. 12 illustrates, clearly greater variation is to be expected over an even more extended time scale bug the relative constancy of serum low-density lipo proteins over the shorter periods indicated is of importance in relation to metabolic studies and allows confidence to be attached to abruptly occurring variations measured in the course of disease processes.

It should be noted that all measurements were carried out in the non-fasting state. It has been shown that dextran sulphate does not react with chylomicro and it was found that total low-density lipoprotein 3 levels did not differ markedly whether the individua? was in the fasting or non-fasting state.

It was observed by Glazier et al. (1954) that a sma increase in $\mathrm{S}_{\mathrm{f}} \mathrm{O}-12$ low-density lipoproteins occurred in the fasting state and that a slight elevation of $\mathrm{S}_{\mathbf{f}} 12-400$ lipoproteins was observable in the non

TABLE V

COMPARISON OF LOW-DENSITY LIPOPROTEIN LEVELS IN SUCCESSIVE ANNUAL INTAKES OF STUDENTS

\begin{tabular}{|c|c|c|c|c|c|c|c|c|c|c|}
\hline \multirow[t]{2}{*}{ Age and Sex Group } & \multicolumn{4}{|c|}{1961 Class } & \multicolumn{4}{|c|}{1962 Class } & \multirow[t]{2}{*}{$t$} & \multirow[t]{2}{*}{ Significance } \\
\hline & No. & Mean & S.E. & S.D. & No. & Mean & S.E. & S.D. & & \\
\hline $\begin{array}{l}\text { Men } 19 \text { and } 20 \\
\text { Women } 19 \text { and } 20\end{array}$ & $\begin{array}{r}16 \\
8\end{array}$ & $\begin{array}{l}420 \\
352\end{array}$ & $\begin{array}{l}20 \cdot 5 \\
15 \cdot 6\end{array}$ & $\begin{array}{l}82 \\
44\end{array}$ & $\begin{array}{r}23 \\
9\end{array}$ & $\begin{array}{l}442 \\
354\end{array}$ & $\begin{array}{l}15 \cdot 2 \\
14 \cdot 7\end{array}$ & $\begin{array}{l}73 \\
44\end{array}$ & $\begin{array}{l}0 \cdot 88 \\
0 \cdot 19\end{array}$ & $\begin{array}{l}<0 \cdot 10 \\
<0 \cdot 10\end{array}$ \\
\hline $\begin{array}{l}\text { Men 21-30 } \\
\text { Women 21-30 }\end{array}$ & $\begin{array}{l}9 \\
9\end{array}$ & $\begin{array}{l}490 \\
397\end{array}$ & $\begin{array}{l}38 \cdot 6 \\
40 \cdot 3\end{array}$ & $\begin{array}{l}116 \\
121\end{array}$ & $\begin{array}{r}22 \\
6\end{array}$ & $\begin{array}{l}509 \\
427\end{array}$ & $\begin{array}{l}20 \cdot 5 \\
40 \cdot 0\end{array}$ & $\begin{array}{l}96 \\
98\end{array}$ & $\begin{array}{l}0.44 \\
0.48\end{array}$ & $\begin{array}{l}<0 \cdot 10 \\
<0 \cdot 10\end{array}$ \\
\hline
\end{tabular}

Men 21-30
Women 21-30

$40 \cdot 3$

116

$40 \cdot 0$

98

0.44
0.48

$<0 \cdot 10$ 

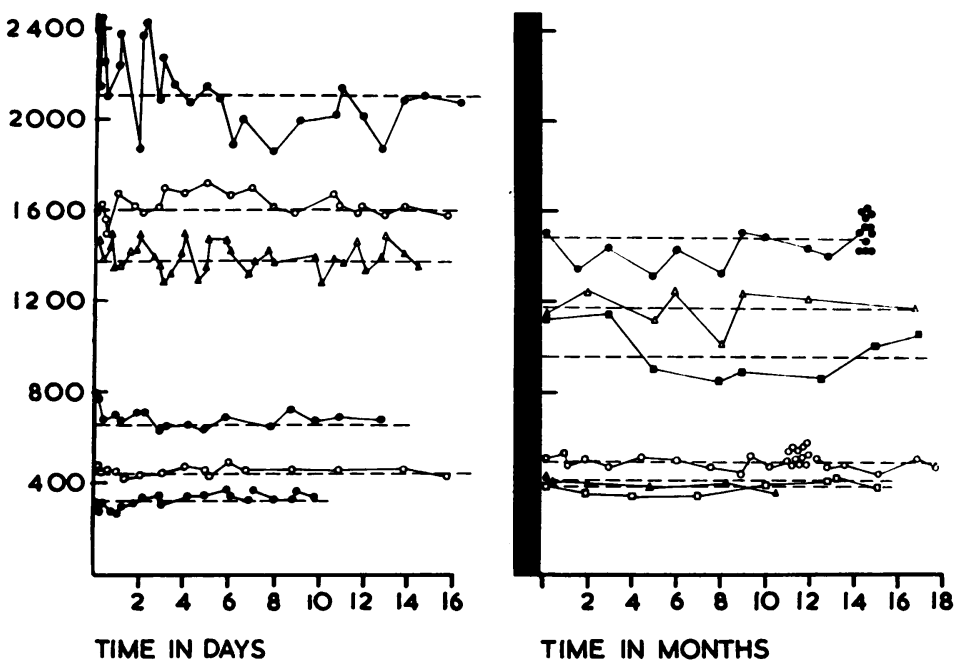

FIG. 14. Range of variation of serum low-density lipoproteins in a given individual encountered in repeated observations over days or months. Range of variation encountered in 12 individuals showing wide variation in mean levels (interrupted lines).

FIG. 15. Serum low-density lipoprotein levels in 50 women (40 thyrotoxic and 10 with myxoedema) with thyroid disease. Note high levels in cases of myxoedema $(\triangle)$ and low or low-normal values in cases of thyrotoxicosis $(\bigcirc)$ as compared with normal range (shaded area).

FIG. 14

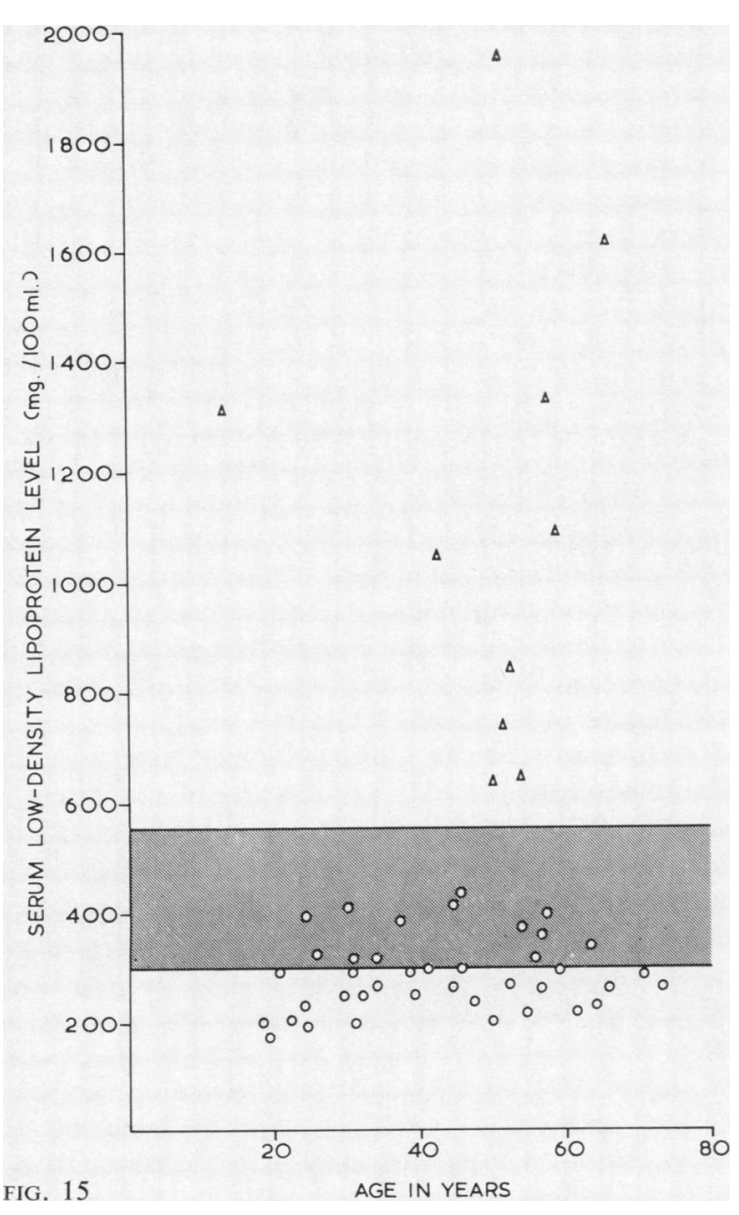

fasting state. Further inspection of the data of these authors established that these changes counterbalanced one another and could probably be regarded as merely a slight redistribution of $\mathrm{S}_{\mathrm{f}}$ classes, since on pooling the data for both $\mathrm{S}_{\mathrm{f}} \mathrm{O}-12$ and $\mathrm{S}_{\mathrm{f}} 12-400$ classes to obtain a figure for total low-density lipoprotein it was found that no significant difference could now be found between levels in fasting and non-fasting subjects, in conformity with the observations made in our own study and referred to above.

LOW-DENSITY LIPOPROTEIN LEVELS IN DISEASE Raised levels were encountered in severe and untreated diabetes, the nephrotic syndrome, xanthomatosis (x. tendinosum, x. tuberosum, and xanthelasma), chronic biliary obstruction, myxoedema and idiopathic hypercholesterolaemia and hyperlipaemia. The significance of altered serum levels in relation to the metabolism of these proteins in the last two conditions named above has been investigated by Walton et al. (1963).

Decreased levels were encountered in thyrotoxicosis, in steatorrhoea arising from a variety of causes (Walton and Jones, 1964), in the terminal phase of liver failure, and in a case of congenital deficiency of low-density lipoproteins (Salt et al., 1960).

The variations in levels encountered in thyroid disease are illustrated in Fig. 15 (see also Scott et al., 1963).

\section{DISCUSSION}

The evidence now presented establishes that the dextran sulphate method is a rapid and simple 
one well suited for population surveys and for use in clinical chemistry. Analysis of the data from the 'normal' population sample examined suggests that low-density lipoprotein levels, like many other biological variables (Wootton and King, 1953), conform to a logarithmic normal distribution, thus accounting for the similar distribution found by other investigators for the lipid components (cholesterol, neutral fats, and phospholipids) carried by these proteins.

Survey of the data in relation to age establishes that mean levels show a slow but significant increase with age. This was found to continue into the seventh and eighth decades in women whereas mean levels decreased in these decades in males. Whether this is a true difference related to sex hormone withdrawal (see below) or whether it merely reflects the greater mortality in males in these decades cannot be determined, since, although similar trends were demonstrable in the data presented by other investigators (see Fig. 13 and Table III), even in these larger surveys the number of individuals examined in the later decades was disproportionately small.

Although there are systematic differences between the absolute values obtained as mean levels at various ages (presumably reflecting technical differences in the methods of estimation and calculation) it can be said that our data and those of Glazier $e t$ al. (1954) agree in demonstrating that significant differences between the sexes exist in adults. Similar differences are suggested (see Table IV) by the more limited figures published by Russ, Eder, and Barr (1951) and those of Furman, Howard, Lakshmi, and Norcia (1961) using different techniques.

Failure to demonstrate differences between mean levels in males and females by Havel et al. (1955) and by Bernfeld et al. (1960) presumably reflects the more restricted female population samples examined by these authors.

Marked differences in serum low-density lipoprotein levels between the sexes were noted to occur over a period corresponding to the reproductive span. This suggests that the balance between male and female sex hormones exerts a determining influence on serum lipoprotein levels in the healthy adult, a preponderance of female hormones tending to be associated with relatively low levels and a preponderance of male hormones conversely associated with relatively high levels. It has already been noted above that, following the climacteric and with gradual diminution of gonadal activity in the later decades, the pattern becomes reversed, serum lipoprotein levels in females equalling and then surpassing levels in the male, the latter actually diminishing in relation to those seen in earlier decades.
Clinical observations also support this suggestion of the direct influence of the sex hormones in tha教 serum lipid patterns have been observed to change following the premature destruction of ovariag function in women (Cochran and Gwinup, 1962 Sznajderman and Oliver, 1963); raised low-densit $\overline{\text { के }}$ lipoprotein levels in men can be markedly reduced bf the administration of oestrogens to the point of producing feminization; and serum levels of low $\overrightarrow{0}$ density lipoproteins in both sexes become raised following treatment with methyl testosterone (Russ. Eder, and Barr, 1955).

Studies in healthy adults using ${ }^{131}$ I-labelled low? density lipoproteins by Scott et al. (1963) and $b \vec{w}$ Walton et al. (1963) suggest that lower serum low density lipoprotein levels in pre-menopausal womeñ are associated with a smaller total body-pool and 3 shorter half-life for this protein than the corre sponding values in men.

The variation in serum low-density lipoprotei levels with age and sex has been held to reflect the relation between age and sex on the one hand anf the incidence of atherosclerosis on the other han $\$$ (cf. Searcy, Carroll, Davis, and Bergquist, 1960) anछ might be considered as another small link in the chain of evidence suggesting a causal relationship between serum low-density lipoprotein levels an this form of arterial disease.

It has been claimed that social class and occupation influence the incidence of cardiovascular disease social class perhaps by way of the variation in the proportion of lipid in the diet imposed by economiô circumstances, and occupation by way of the variation in the amount of physical exercise entaile in certain trades and avocations (Morris et al., 1953) The small population sample examined in the presen investigation did not show any significant differences in mean lipoprotein levels in individuals engage $\bar{\Phi}$. predominantly in manual occupations as opposed to those found in an overall population sample which was weighted in favour of individuals io sedentary work (see Table II).

However, the ease and simplicity of the dextram sulphate method for surveys of this kind man commend its use to those who wish to re-examine this point using groups more clearly segregated in social class and occupation.

In this connexion also, it should be noted that in the earlier publications of Gofman and his groug (cf. Gofman, Jones, Lindgren, Lyon, Elliott, and Strisower, 1950; Gofman, Glazier, Tamplin, Strisg ower, and DeLalla, 1954) particular emphasis was placed on the significance of increase of a particulas class $\left(\mathbf{S}_{\mathrm{f}} 10-20\right)$ of low-density lipoproteins i⿱ association with the incidence of atherosclerosi The $S_{p}$ classes are known to be distributed essential 
bimodally, the primary peak $\left(\mathrm{S}_{\mathrm{f}} 3-9\right)$ having a mode at about $\mathrm{S}_{\mathrm{f}} 6$ and the secondary skewed and asymmetrical peak $\left(\mathrm{S}_{\mathrm{f}} 20-400\right)$ a mode at about $\mathrm{S}_{\mathrm{f}} 35$. The trough between these peaks represents the $\mathrm{S}_{\mathrm{f}}$ 10-20 class and could well represent the overlapping 'tails' from the major peaks since $S_{\boldsymbol{f}}$ classes from both major peaks are found to be represented in this class when the flotation distribution is analysed (Oncley, 1955; Oncley et al., 1957). Overall increase of the low-density lipoproteins may be brought about by increase of both major peaks or by increase of one at the expense of the other. Even when the increase is predominantly of the one peak, there is invariably also increase of the height of the trough region between the major peaks, presumably because of the increased contribution of the 'tail' of the enlarged peak. On this basis, increase of the $S_{\mathrm{f}}$ 10-20 class could be looked upon merely as an indicator of overall increase of low-density lipoproteins rather than as an increase of a class of molecules in some way specifically related to correlative disease processes.

The various $S_{f}$ classes are immunologically indistinguishable (Walton and Darke, 1963), so clearly a method providing information about the overall level only of low-density lipoproteins may be of equal value in exploring further the association between serum lipid changes and arterial disease although recourse to ultracentrifugal characterization of the distribution of $S_{f}$ classes may still be necessary for other diagnostic purposes.

Our grateful thanks are due to Dr. C. R. Ricketts for many helpful suggestions and for the supply of dextran sulphate; to Dr. S. J. Darke, and Mrs. E. Albert for paper electrophoretic examinations and for allowing us to use their data; to Dr. J. W. L. Davies for radioactive labelling of proteins; and to Dr. B. Ingelman of Pharmacia Ltd., for generous samples of commercial dextran sulphate.

We are indebted to Dr. E. Bulmer for allowing us access to patients under his care in the United Birmingham Hospitals; Mr. T. Whitehead for the supply of sera and permission to include the results of cholesterol determinations; Dr. W. Weiner and the staff of the Midland Regional Blood Transfusion Centre for surplus serum from blood donors, and to the late Mr. H. R. Salt and the staff of the Biochemistry Department, Birmingham Children's Hospital, for the supply of sera from children.

\section{REFERENCES}

Antoniades, H. N., Tullis, J. L., Sargeant, L. H., Pennell, R. B., and Oncley, J. L. (1958). J. Lab. clin. Med., 51, 630.

Bernfeld, P., Berkowitz, M. E., and Donahue, V. M. (1957). J. clin. Invest., 36, 1363.

_-, Bonner, C. D., and Berkeley, B. J. (1960). Ibid., 39, 1864.
Nisselbaum, J. S., Berkeley, B. J., and Hanson, R. W. (1960). J. biol. Chem., 235, 2852.

Cochran, R., and Gwinup, G. (1962). Arch. intern. Med., 110, 162.

Cornwell, A. G., Kruger, F. A., Hamwi, G. J., and Brown, J. B. (1961). Amer. J. clin. Nutr., 9, 24.

Crockson, R. A. (1962). J. med. Lab. Technol., 19, 243.

DeLalla, O. F. and Gofman, J. W. (1954). Meth. biochem. Anal., 1, 459.

Furman, R. H., Howard, R. P., Lakshmi, K., and Norcia, L. N. (1961). Amer. J. clin. Nutr., 9, 73.

Gitlin, D., Cornwell, D. G., Nakasato, D., Oncley, J. L., Hughes, W. L. Jr., and Janeway, C. A. (1958). J. clin. Invest., 37, 172.

Glazier, F. W., Tamplin, A. R., Strisower, B., DeLalla, O. F., Gofman, J. W., Dawber, T. R., and Phillips, E. (1954). J. Geront., 9, 395.

Gofman, J. W., Glazier, F., Tamplin, A., Strisower, B., and DzLalla, O. (1954). Physiol. Rev., 34, 589.

_, Jones, H. B., Lindgren, F. T., Lyon, T. P., Elliott, H. A., and Strisower, B. (1950). Circulation, 2, 161.

Havel, R. J., Eder, H. A., and Bragdon, J. H. (1955). J. clin. Invest., $34,1345$.

Heiskell, C. L., Fisk, R. T., Florsheim, W. H., Tachi, A., Goodman, J. R., and Carpenter, C. M. (1961). Amer. J. clin. Path., 35, 222.

Henly, A. A. (1957). Analyst, 82, 286.

Keys, A., and Grande, F. (1957). Amer. J. publ. Hlth, 47, 1520.

Lever, W. F.. Gurd, F. R. N., Uroma, E., Brown, R. K., Barnes, B. A., Schmid, K., and Schultz, E. L. (1951). J. clin. Invest., 30, 99.

Lindgren, F. T., and Nichols, A. V. (1960). In The Plasma Proteins, edited by F. W. Putnam, vol. 2, p. 1. Academic Press, New York and London.

McFarlane, A. S. (1956). Biochem. J., 62, 135.

Morris, J. N., Heady, J. A., Raffle, P. A. B., Roberts, C. G., and Parks, J. W. (1953). Lancet, 2, 1053, 1111.

Oncley, J. L. (1955). In Proc. 7th Ann. Conf. on the Nephrotic Syndrome, Boston, Mass., Oct., 1955, edited by J. Metcaff, p. 68. National Nephrosis Foundation, New York.

_- and Gurd, F. R. N. (1953). In Blood Cells and Plasma Proteins, Their State in Nature, edited by J. L. Tullis, p. 337. Academic Press, New York.

, Walton, K. W., and Cornwell, D. G. (1957). J. Amer. chem. Soc., 79, 4666 .

Page, I. H., Kirk, E., Lewis, W. H. Jr., Thompson, W., and Van Slyke, D. D. (1935). J. biol. Chem., 111, 613.

Pearsall, H. R., and Chanutin, A. (1949). Amer. J. Med., 7, 297.

Ricketts, C. R. (1952). Biochem. J., 51, 129.

, Walton, K. W., Van Leuven, B. D., Birbeck, A., Brown, A., Kennedy, A. C., and Burt, C. C. (1953). Lancet, 2, 1004.

Russ, E. M., Eder, H. A., and Barr, D. P. (1951). Amer. J. Med., 11, 468.

$-, \frac{1}{-},-$ (1955). Ibid., 19, 4.

- , Raymunt, J., and Barr, D. P. (1956). J. clin. Invest., 35, 133.

Salt, H. B., and Wolff, O. H. (1957). Arch. Dis. Childh., 32, 404. , Lloyd, J. K., Fosbrooke, A. S., Cameron, A. H., and Hubble, D. V. (1960). Lancet, $2,325$.

Sasaki, S., and Noguchi, H. (1959). J. gen. Physiol., 43, 1.

Scanu, A., and Page, I. H. (1959). J. exp. Med., 109, 239.

Scott, P. J. (1962). Serum \& lipoproteins in health and disease. M.D. Thesis, University of Birmingham.

_- Dykes, P. W., Davies, J. W. L., and Walton, K. W. (1963). In Biochemical Problems of Lipids, edited by A. C. Frazer, p. 318. Elsevier, Amsterdam.

Searcy, R. L., Carroll, V. P., II, Davis, W. H., and Bergquist, L. M. (1960). Lancet, 2, 1196.

Soothill, J. F. (1962). J. Lab. clin. Med., 59, 859.

Strong, L. E. (1948). In Encyclopedia of Chemical Technology, edited by R. E. Kirk, and D. F. Ottmer, vol. 2, p. 556. Interscience, New York.

Sznajderman, M., and Oliver, M. F. (1963). Lancet, 1, 962.

Walton, K. W. (1952). Brit. J. Pharmacol., 7, 370.

-, and Darke, S. J. (1963). In Protides of the Biological Fluids, edited by H. Peeters, vol. 10, p. 146. Elsevier, Amsterdam. and Jones, J. H. (1964). In preparation.

-, Scott, P. J., Verrier Jones, J., Fletcher, R. F., and Whitehead, Y. (1963). J. Atheroscler. Res., 3, 396.

Woctton, I. D. P., and King, E. J. (1953). Lancet, 1, 470. 